Available online at http://dergipark.gov.tr/iujad Inonu University Journal of Art and Design

Faculty Homepage: http://www.inonu.edu.tr/tr/gsf

\title{
Doğu Karadeniz Kırsal Mimari Örneği Serenderlerin Ekoloji ve Sürdürülebilirlik
} Bağlamında İncelenmesi

\section{Research On "Serender", Rural Architecture Practices Of Eastern Black Sea Region, In The Context Of Ecology And Sustainability}

\section{Selda AL SENSOYa*@id, Sibel KUKOĞLU b@iD}

a Recep Tayyip Erdoğan Üniversitesi, Güzel Sanatlar Tasarım ve Mimarlık Fakültesi, Mimarlık Bölümü, Rize, 53100, Türkiye

b Yüksek Mimar, Rize, 53100, Türkiye

Article history: Received 09-05-2020 / Accepted 23-05-2020

\section{OZET ABSTRACT}

\begin{abstract}
Geçmişi günümüze taşıyan geleneksel yapıların korunması kültürel süreklilik açısından önemli bi konudur. Bu bağlamda Doğu Karadeniz Bölgesi genelinde önemli kırsal mimari örneklerden biri olan serenderler çalışma kapsamında ele alınmıştır. Mevcut serenderlerin korunması, yeniden işlev kazandırılması ve gelecek nesillere aktarılabilmesi için çözüm önerileri sunulmas çalışmanın amacını oluşturmaktadır. Unutulmaya yüz tutmuş serenderler ekolojik ve sürdürülebilirlik kriterler üzerinden incelenmiştir. Bu doğrultuda Trabzon İlinin serenderlere sık rastlanan Sürmene, Tonya ve Arakl İlçelerinde alan çalışması yapılmıştır. Her ilçeden 5 serender seçilerek ve toplamda 15 adet serender yerinde tespit yöntemiyle incelenmiştir. Her bir serenderi ekolojik ve sürdürülebilirlik açısından analiz etmek için belirlenen kriterler doğrultusunda kontrol listeleri oluşturulmuştur. Elde edilen veriler ve gözlemler doğrultusunda tüm serenderler için saptanan analiz ve bulgular genel bi tablo ile ortaya konulmuştur. Elde edilen bulgular sonucunda serenderlerin ekolojik ve sürdürebilirlik kriterlerine uyumlu oldukları saptanmıştır. Sonuçlar değerlendirilerek serenderlerin korunması ve gelecek nesillere aktarılabilmesi için çözüm öneriler sunulmuştur.
\end{abstract}

Anahtar Kelimeler: Kırsal Mimari, Serender, Ekoloji, Sürdürülebilirlik, Trabzon
The preversation of traditional buildings that carry the past to the present day is an important issue in terms of cultura continuity. In this context, serenders one of the most important vernecular architectural examples in the Eastern Black Sea Region, were discussed in the study. The aim of the study is to achieve solutions for the protection, refunctionalization and transfer of present serenders to future generations. The completely forgotten serenders were examined on ecological and sustainability criteria. Within this scope, field surveys were carried out in Surmene, Tonya and Araklı districts of Trabzon Province, where serenders were seen common. 5 serenders were selected from each district and totally 15 serender were examined in their own locations. In order to analyze each serender in terms of ecology and sustainability, checklists were prepared in accordance with the determined criteria. In the light of the obtained data and observations, the analysis and findings for all serenders were presented in a genaral table. As a result of the findings, it was determined that the serenders are compatible with the ecological and sustainability criteria. Solutions were proposed by evaluating the results for the protection of the serenders and transmitting them to future generations.

Keywords: Rural Architecture, Serender, Ecology, Sustainability, Trabzon.

\section{GİRIŞ}

İnsanoğlu, varoluşundan günümüze kadar gelen süreçte doğanın fiziksel şartlarından kendini korumak ve barınma ihtiyacını karşılamak için sürekli bir mekân üretme/arayışı içinde olmuştur. İlk başlarda çevresindeki malzemeleri kullanarak inşa ettiği ilkel yapılar zamanla deneyimlerin artması, teknolojik gelişmeler ve ihtiyaçların değişmesiyle daha kompleks hale gelmiştir. Gerek yurt dışında gerek yurt içinde uzun bir süreç sonunda gelişen günümüz mimarisine bakıldığında doğrudan ya da dolaylı olarak temelinde geçmişin izlerinin bulunduğu görülmektedir.

Geleneksel mimari, bir yörenin kimliğini oluşturan, geçmişteki insanların yaşam ve kültürlerinden izler taşıyan geleneksel dokuyu bünyesinde barındırmakta ve geleceğe ışık tutmaktadır Geleneksel mimarinin bir parçası olan kırsal mimari, şehirden uzak halen varlığını sürdürmeye çalışan ve halkbilimi açısından büyük önem taşıyan kültürel değerlerden biridir. Gerek kullanılan yapı malzemesi gerek inşa tarzı bakımından kırsal kesimlerde çeşitli peyzajlar

* Corresponding author

https://www.doi.org/10.16950/iujad.734769 
yaratan bu mimari ne yazık ki değişik sebeplerle her geçen gün biraz daha azalmakta, yerine yenileri yapılmamakta, mevcut durumdakiler ise bakımsızlık, değişen sosyo-ekonomik ve sosyo-kültürel şartlar sonucu kaybolma riskiyle karşı kalmaktadır (Ceylan, 2010).

Yapay bir üsluba bürünmek yerine kendine has bir karaktere sahip, endüstriyel dönem öncesi toplumların gereksinimlerine, topoğrafya ve iklimin zor şartlarına çözüm sunan geleneksel yapılar, estetik, yalın ve özgün halleriyle tarihe ışık tutmaktadır (Tuna, 2008). İnsanların çevreyle olan etkileşimlerini yansıtan ve bulunduğu ortamın doğal dokusuna saygılı olan kırsal mimari aynı zamanda yöresel mimari kimliği de ortaya çıkarmaktadır. İnsanların yaşam şartlarının zorlukları karşısındaki davranışlarının kültüre yansımasının bir ifadesi olan kırsal mimari, gelenek ve göreneklere bağı yöre halkının yaşamında önemli bir yere sahiptir.

İnsanoğlu günlük yaşantısı içinde çeşitli gereksinimleri için bilinçli veya bilinçsiz bir yapı eylemi gerçekleştirmektedir. Korunma içgüdüsünden dolayı barınak yapma arayışına giren ilk insanların basit korunakları mimari yapı eylemlerinin başlangıcı olarak nitelendirilmektedir. En ilkelinden en gelişmişine kadar mimari yapıların tümü bir boşluğu sınırlandırma ve bir mekan oluşturma amacını taşımaktadır (Sağsöz vd., 2008). Bu bağlamda bireyin yaşamını sürdürülebilmesi için insanlık tarihi boyunca birtakım mekanlara ihtiyacı olmuştur. Hemen hemen her yörenin kırsalında konutun yanında özelleşmiş ikincil yapı türlerine rastlanmaktadır. Doğu Karadeniz kırsal alanında yaşayan yöre insanının barınmasını sağlayan birincil yapı türü olan konuta ek, ürünleri saklamak ve depolamak için kullandığı geleneksel yapı türlerinden çöten, dam, serender, ocak, ahır, samanlık ve kümes yardımcı eleman olarak önem kazanmıştır (Eruzun, 1977).

Konutun yanında yer alan ikincil yapı türlerinden biri olan serenderler, yapımında kullanılan yerel malzeme, çok özgün yapısal ve mimari zenginliğiyle köy insanının bol yağışlı ve nemli bir iklime sahip olan Karadeniz Bölgesi'nde yiyecekleri yağmur ve nemden koruyarak kurutup saklamak için tabiat şartlarına karşı bulduğu rasyonel ve pratik çözümlerin en sade örneklerindendir (İskender, 2010). Karadeniz Bölgesi'ne özgü tipolojik bir öğe olan serender, aslında besinlerin bozulmadan saklanabilmesi amacıyla evlerin hemen yanına yapılan, iç kısmında oturulmayan ve yaşanmayan dolayısıyla tek işlevli, sade bir mekan düzeneği olan yapıdır (Batur ve Gür, 2005) (Şekil 1).

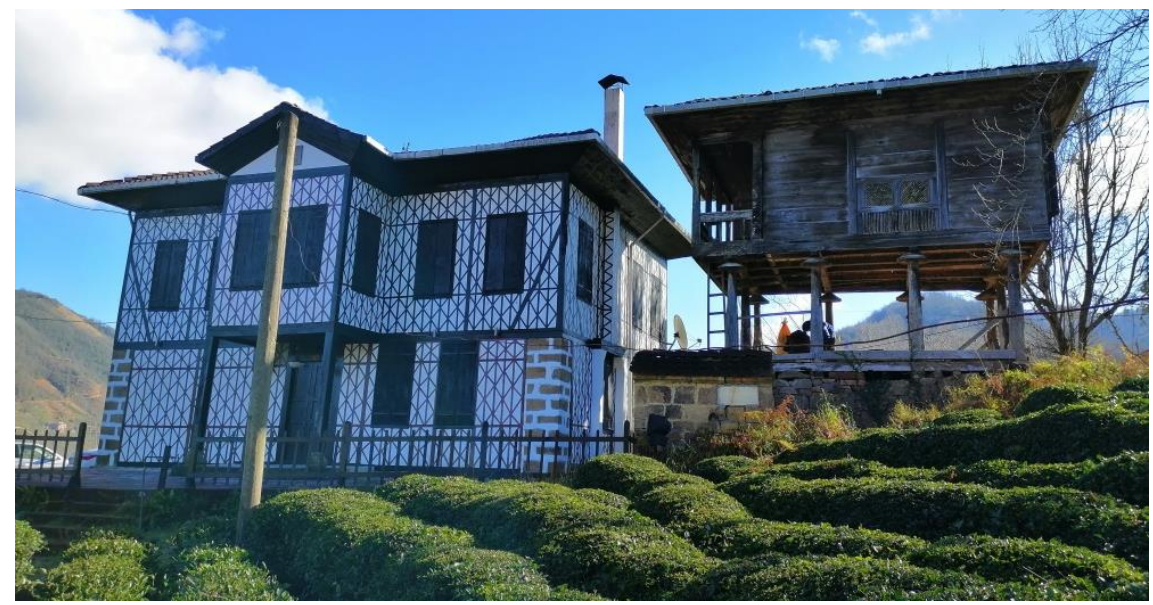

Şekil 1. Serender konut ilişkisi, Sürmene-Aksu Mahallesi/Trabzon

İnsanlık tarihi boyunca kendisine yer edinen kültürler mimari yapılarıyla da tanınmaktadır. Ne yazık ki kırsal yapıların tarihsel sürekliliği, endüstriyel ürünler ve hızlı gelişen iletişim tekniklerinin neden olduğu sosyal karmaşanın tehdidi altındadır. Kırsaldaki bu yapıların birçoğu kalitesiz yapılaşma nedeniyle bozulmakta veya kentlere göç yüzünden bakımsız kalmaktadır (Aran, 2000). Günümüzde giderek birbirinin benzeri olan kentlerdeki aynı yapı tiplerine karşın kırsal bölgelerde yerleşimler; bulundukları bölgenin fiziksel koşullarını, sosyokültürel yapısını, ait oldukları dönemin yaşam şeklini ülkemizin kültürel zenginliği içinde bölgeden bölgeye farklı şekillerde mekanlarına yansıtmaktadır (Akansel vd., 2009). 
Kırsal alanda yaşayan insanlar işsizlik, imkanların kısıtlı olması, ulaşım sorunları, topoğrafik yapı, barınma ihtiyacı gibi çeşitli nedenlerle kentlere göç etmeyi tercih etmişlerdir. Kırsal dokudan uzaklaşan insanlar sahip oldukları kültürlerinden ve geleneksellikten uzaklaşarak kent yaşamını benimsemişlerdir. Bu durum da geleneksel yapı türlerinin işlev ve önemini kaybetmesine neden olmuştur. Doğanın eşsiz güzelliğine uyum sağlayan çevre dostu serenderler de işlev ve önemini kaybeden geleneksel yapılardandır.

Karakteristik yapıları, yapım teknikleri, strüktürleri farklı olsa da yerel ve doğal malzemelerle inşa edilen geleneksel mimariye bakıldığında, bulunduğu çevrenin koşullarına uygun rasyonel çözümlere sahip olması, doğaya zararsız tasarımı ile günümüz mimari uygulamalarını oluşturan ekolojik ve sürdürülebilir mimarlık kavramının temelini oluşturduğu söylenebilir. Bu bağlamda çalışmada, estetik görünüme sahip ve doğaya uygun tasarımlı fakat unutulmaya yüz tutmuş, fonksiyonunu yitiren serenderler ekolojik ve sürdürülebilirlik kriterleri kapsamında analiz edilmiştir. Elde edilen bilgiler ışığında doğa dostu bu mimari yapıların varlığını koruyabilecek öneriler sunulmuştur. Böylelikle, çalışma ile serenderler hakkında gelecek nesillere ışık tutulması, mevcut serenderlerin korunması ve yeniden işlevlendirilmesi konusunda kültürel mirasa katkı sağlanması hedeflenmektedir.

\subsection{Geleneksel Yapı Olarak Serenderler}

Engebeli bir araziye sahip olan Doğu Karadeniz Bölgesi'nde kırsal alanlar şehir ve kasabalara göre daha kısıtlı ulaşım olanaklarına sahiptir. Toplumun sosyal ve kültürel yapısıyla birlikte varlığını sürdürebilmesi, beslenme sorunun çözümlenmesi ve üretilen gıda maddelerinin bozulmadan korunmasını zorunlu kılmaktadır (Eruzun, 1977). Yağışlı iklime ve engebeli topografyaya sahip Doğu Karadeniz Bölgesi'nde bol yağıştan dolayı havadaki ve topraktaki nem oranı fazladır. Nem gıda malzemelerinin korunmasını olumsuz yönde etkilemektedir. İşte bu noktada depolama alanı direklerle zeminden yükseltilmiş serenderler köy insanının tabiat şartlarına karşı bulduğu akılcı ve pratik çözümlerin bir örneğidir (İskender, 2010).

'Serin, havadar yer' anlamına gelen serenderler, Karadeniz'in değişik bölgelerinde, 'serenti, nayla, tekir (Beşikdüzü), paska (Sürmene), bagen, ayvan' gibi farklı isimlerle adlandırılmaktadır. Sinop ilinden itibaren Sarp Sınır Kapısına kadar Karadeniz Bölgesi'nde rastlanan bu mimari öğelerin en güzel örnekleri Trabzon, Rize ve Artvin illerinde görülmektedir (Aksoylu, 2012; Özgüner, 1970).

Antropolojik araştırmalar ve kültürler arası karşılaştırmalar insanların aynı şartlarda benzer çözümler ürettiğini ortaya koymaktadır. Dünyada Doğu Karadeniz Bölgesi'ne benzer iklim özelliklerine sahip kırsal kesimlerde, insanların tarım ürünlerini gerek nemden gerekse hayvanlardan muhafaza etmek amacıyla inşa ettikleri ambar yapıları da şaşırtıcı benzerlikler göstermektedir (İskender, 2010). Karadeniz Bölgesine özgü serenderler ülkemizde ve dünyada da farklı biçimleniş ve adlandırmalarla karşımıza çıkmaktadır. Avrupa'da Alpler'de ve İspanya'da 'loft' olarak adlandırılan serendere benzer bir yapı türü bulunmaktadır. Loft kelimesi 'yüksek yer, yapı' anlamı olarak tanımlanır (Karpuz, 1999). Serender benzeri yapılar Galiçya/İspanya'da "horreo", Norveç'de "loft", Gürcistan'da "nalia", İsveç'te "storehouse", Portekiz'de "espigueiros", Slovenya'da "kozolec", Japonya'da "takakura" olarak adlandırılmaktadır ( Özgel Felek, 2020) (Şekil 2).
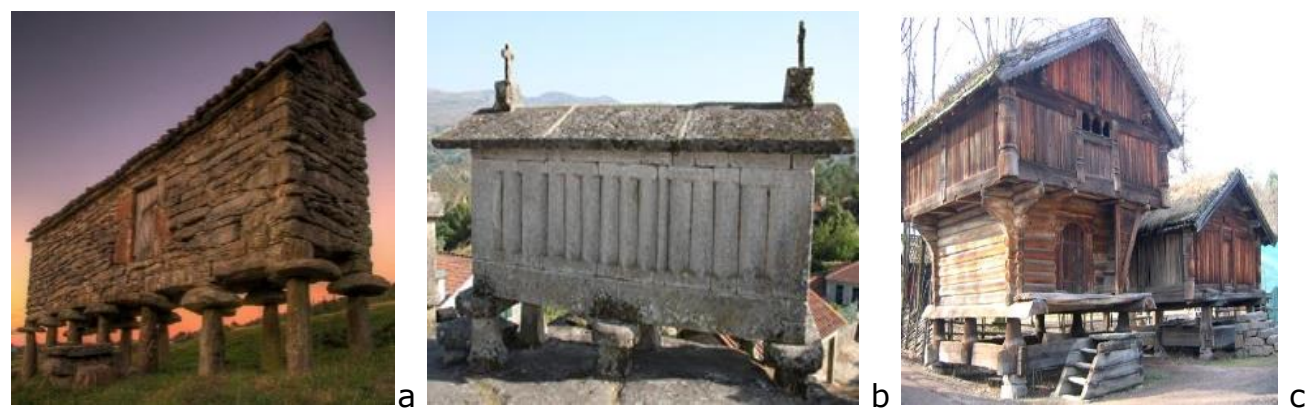

Şekil 2. Dünyadaki serender benzeri depolama yapısı örnekleri, İspanya (a), Portekiz (b), Norveç (c), (URL-1, 2019; URL-2, 2019; URL-3, 2019) 
Doğu Karadeniz Bölgesi kırsal mimarisinin karakteristik unsurlarından biri olan serenderlere günümüzde farklı işlev ve konumlarda rastlanılmaktadır. Kırsalda çoğu serenderler bilinçsizce yıkılmış ve bakımsızlıktan birçok özelliğini kaybetmiş olsa da halen bazı köylerde evlerin yanında varlıklarını korudukları görülmektedir. Fakat bu serenderler eskisi gibi yiyecek depolama yerine eski eşya-yakacak deposu veya çardağında, zeminde gölgelikli oturma alanı olarak kullanılmaktadır. Sökülüp taşınabilir özelliğe sahip olan serender bazen de kültürel sürekliliğin sağlanması amacıyla kırsaldan kent merkezlerine taşınarak çay bahçesi elemanı, kütüphane, kentsel donatı vb. farklı amaçlarda kullanılmaktadır.

Doğu Karadeniz'in dağınık bir şekilde kurulmuş köylerinde çok sık rastlanılan serenderler yerel ustaların ince ağaç işçilikleri, iç kısmında oturulmayan ve yaşanmayan dolayısıyla tek işlevli yapısıyla kırsaldaki konutun değişmez komşularından biridir. Yerine göre zeminden 150-200 cm yükseklikte, büyüklüğüne göre 4-12 direk üzerine oturtulmuş, genellikle 2 katlı (kimilerinde de ambar tavanı yüksek tutularak araya bir asma kat eklenir) bir yapıdır (Şekil 3).
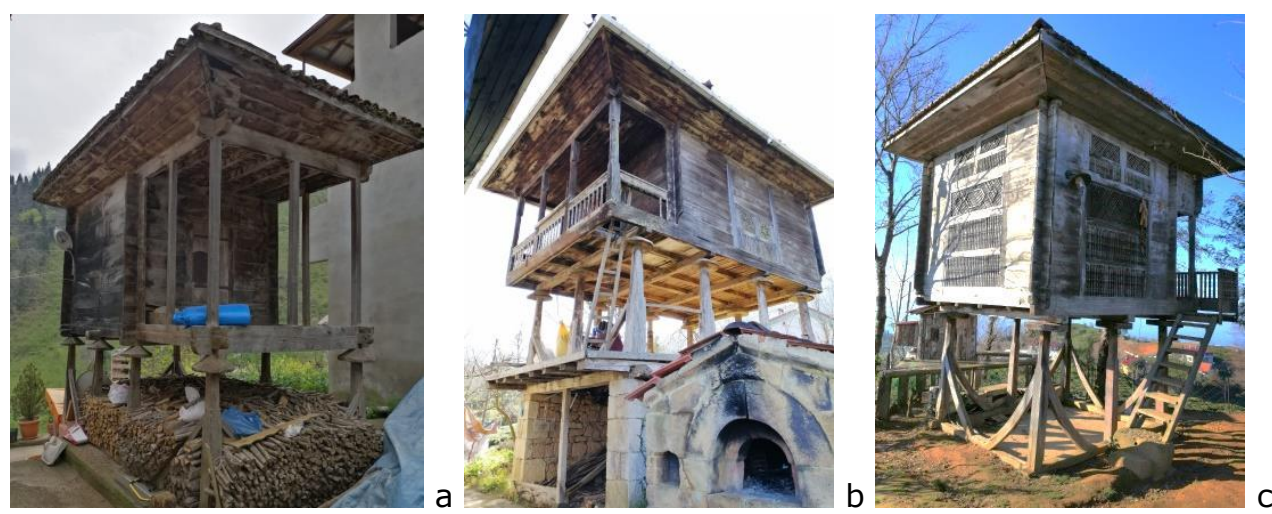

Şekil 3. Farklı Büyüklüklerdeki Serender Örnekleri, Araklı (a), Sürmene (b), Dernekpazarı (c)

Yağışlı iklime bağlı olarak Doğu Karadeniz Bölgesi'nde havadaki ve topraktaki nem oranı fazladır. Nem gıda malzemelerinin korunmasını olumsuz yönde etkiler, bu nedenle serenderlerin alt kısmı doğal havalandırmanın sağlanması, zeminden gelen nemin engellenmesi amacıyla sadece dikmelerden oluşmakta, ana kapalı kısım ise üstte yer almaktadır. Üst kısmı depolama alanı olarak kullanılan serenderlerin direkleri arasındaki yarı açık alt kısmı ise farklı eylemlere ev sahipliği yapabilmektedir. Serenderlerin altı odun depolamak, hayvan yiyeceği kurutmak, sonbaharda pekmez pişirmek, yaz sıcaklarında gölgede dinlenmek için kırsalda en fazla kullanılan mekanlardandır.

Serenderler, mısır, fasulye, çeşitli meyve kuruları, kabak, patates, soğan ve fındık gibi mevsime göre yetişen gıda malzemelerini sıcaktan, soğuktan, bölgenin özelliği olan yüksek nemden koruyarak bozulmalarını ve çürümelerini önlemektedir. Bu tür gıda malzemeleri serenderlerin ambar kısmının zemininde veya duvarlarda yer alan özel bölmelerde saklanır. Günümüzdeki antrepo ve soğuk hava depolarına göre serenderlerin daha sağlıklı bir muhafaza sistemi olduğu da söylenebilir (Aksoylu, 2012).

Plan şemaları kare ya da dikdörtgen olan serenderler büyüklüklerine ve ambar-çardak ilişkisine göre iki bölümde incelenebilir. Büyüklüklerine göre serenderler 3'e ayrılır. Bunlar; küçük (4 direkli), orta (6-8 direkli) ve büyük (10-12 direkli) serenderlerdir (Şekil 4). Ambar ve çardak ilişkisine göre serender çeşitleri ise ön taraflı, ön ve tek taraflı, ön ve iki taraflı ve dört taraflı çardaklı serenderlerdir (Şekil 5). Bu tipler, yerleşme biriminin gereksinmelerine göre ortaya çıkmaktadır. Çardakla ilgili işlevler arttıkça çardak alanı da artmaktadır. Ayrıca serenderlerin büyüklüğü ailenin ekonomik durumu ile doğru orantılıdır (Eruzun, 1977). 


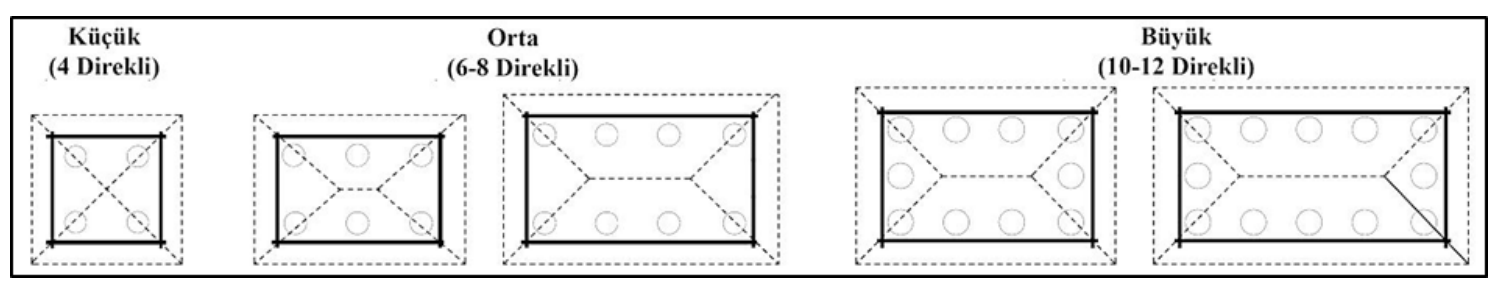

Şekil 4. Büyüklüklerine göre serender çeşitleri

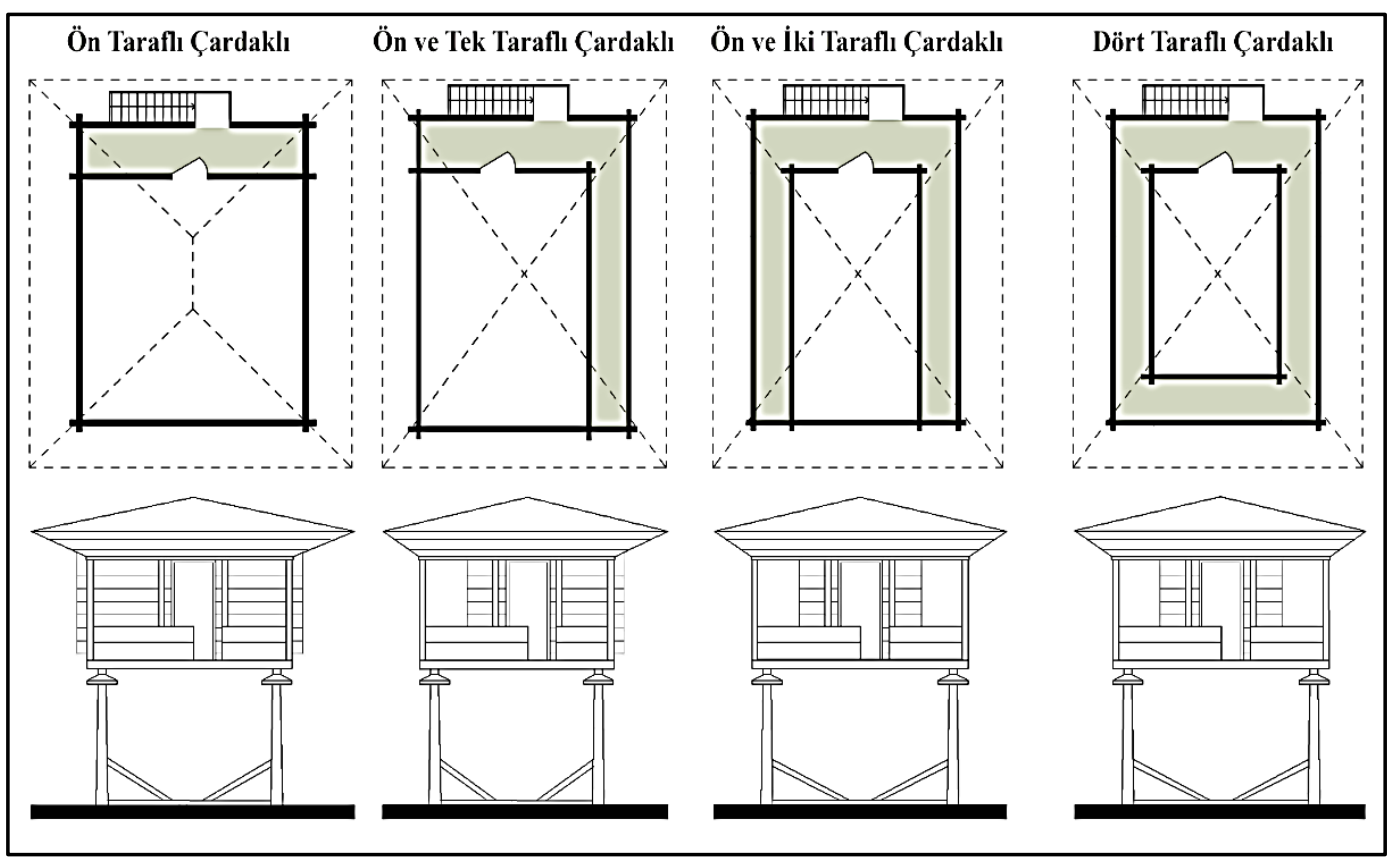

Şekil 5. Ambar ve çardak ilişkilerine göre serender çeşitleri

\subsection{Serenderlerin Yapısal Özellikleri ve Yapım Tekniği}

Serenderlerin yapılacağı yer belirlenirken eve en yakın ve uygun arazi seçilmektedir. Çünkü serenderi kullanacak evin tüm yiyecekleri burada korunmakta ve dolayısıyla da konut ile serender arasında gün boyunca birçok kez gidilip gelinmektedir (Demir, 2004). Doğu Karadeniz Bölgesi'nin kapalı ekonomi sisteminin geçerliligği ve ulaşım olanaklarının kısıtlı oluşu, yerel yapı malzemelerinin kullanılmasını zorunlu kılmaktadır. Bölge için önemli yerel yapı malzemesi ahşaptır. Yapı için malzemenin dış etkenlere karşı dayanıklı olması çok önemlidir. Bu nedenle serender yapımında çoğunlukla kestane ağacı olmak üzere ardıç ve ceviz gibi dayanıklı ağaç türleri kullanılmaktadır. Temel bölümünde ise genellikle moloz taş veya karataş malzemesi kullanılmaktadır (Eruzun, 1977, Topaloğlu, 1998).

Serenderlerin kontrüksiyonu sırasıyla; yastık taşı, taban ağacı (seren), dirsek (yanlama/çalman), direk, teker, direk başı, kirişler, çardak direği, çardak direği başı, makas direği, makas ağaçları, omuz başı, mertek ve hartamadan (günümüzde kiremit veya sac) meydana gelmektedir (Özgüner, 1970) (Şekil 6). 

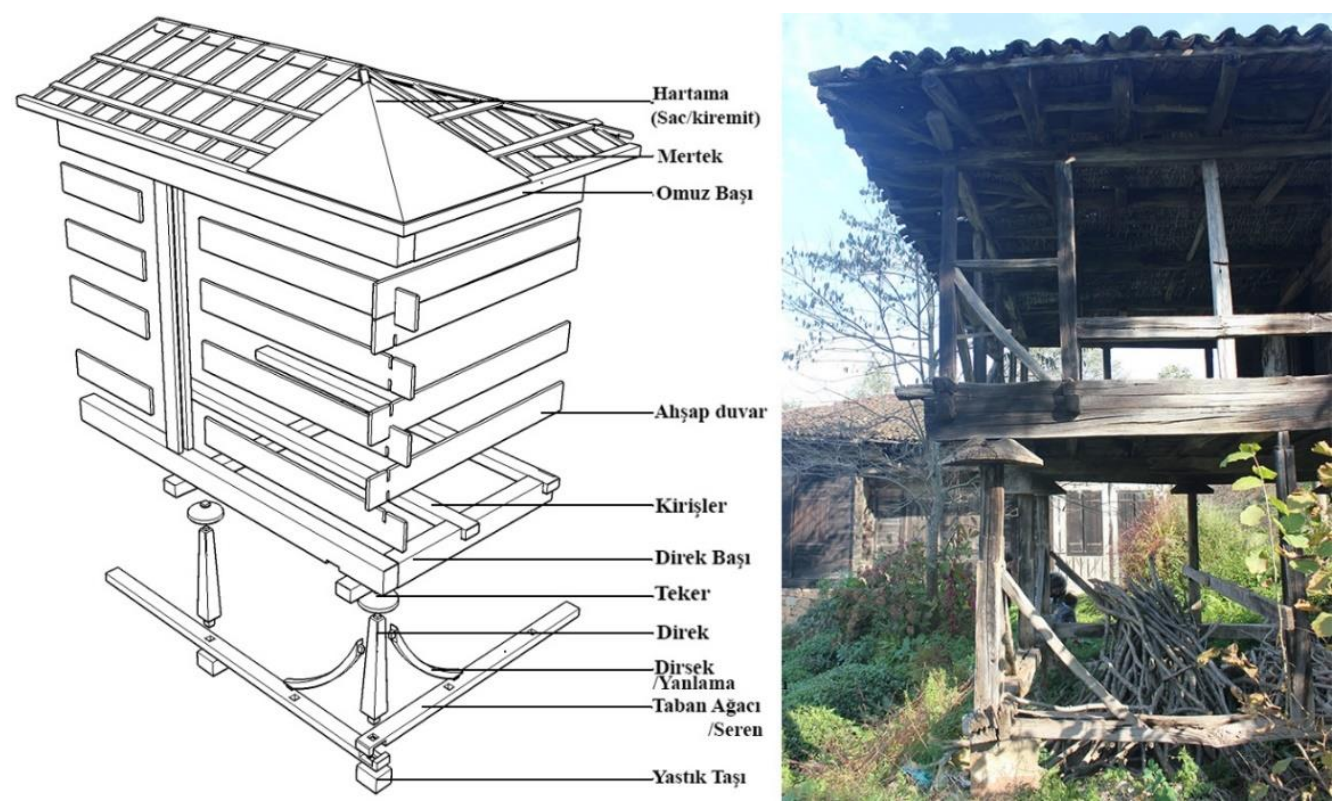

Şekil 6. Serenderin konstrüksiyonu

Serender yapımının ilk aşaması olarak toprağın kazılarak düzeltilmesi gerekmektedir. Arazinin düz olduğu yerlerde yapılacak kazı miktarı da azdır. Zeminin ağaçla temasını önlemek amacı ile tabanda yatay şekilde bulunan ve 'seren' adı verilen kalın kalaslar ile toprak arasına 'yastık' denilen düzgün yüzeyli taşlar yerleştirilmektedir. Taşlar, nemin fazla olduğu bu bölgede, ahşabın zemin ile temasını keserek çürümesini önlemek için kullanılmaktadır (Demir, 2004) (Şekil 7). Bazen de direkler doğrudan zemine oturtulur.
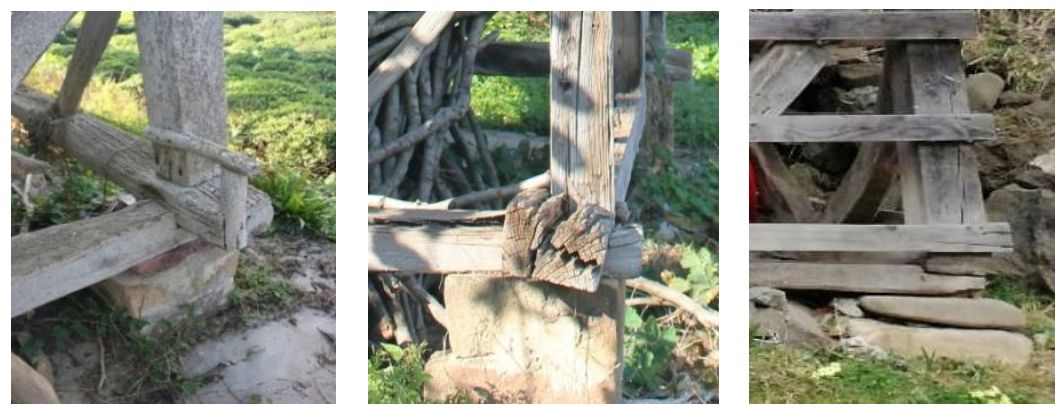

Şekil 7. Serenderin zeminle bağlantısı

Serenderlerin kendine özgü strüktürü, ahşap karkas ve ahşap yığma tekniğinin birlikte kullanımından oluşmaktadır. Zemindeki yastık taşlarının üzerine köşeleri yarım geçme ile birleşen taban ağaçları (seren) yerleştirilir. Bütün direkler taban ağaçlarına geçme tekniği ile oturtulur. Direklerin baş tarafına 40-60 cm çapında, 8-20 cm yüksekliğinde, konik formlu tekerler takılır. Tekerlerin üzerine $10 \times 15-15 \times 20 \mathrm{~cm}$ kesite sahip direk başlığı denen ana kirişler yerleştirilir (Şekil 8). Bunların üzerine yine yarım geçme ile bindirilen kirişleme yapılır. Kirişlemelerle konsol oluşturularak ambar kısmının genişlemesi sağlanır.

Serender direği tabanda daha kalınken tekerleklerin olduğu üst kısımda kalınlık azalmaktadır. Köşelerde bulunan ve çapraz şekilde yerleştirilen yanlama (dirsek/çalman) ismi verilen kalaslar yapıyı iki taraftan desteklemektedir. Dört köşede de benzer yol izlendiği için yapı oldukça dayanıklı olmaktadır (Şekil 8) (Demir, 2004). Kimi yörelerde ahşap direkler zamanla eskidiği ve taşıyıcılık özelliğini kaybettiği için yerine beton direkler yapılmaktadır. 

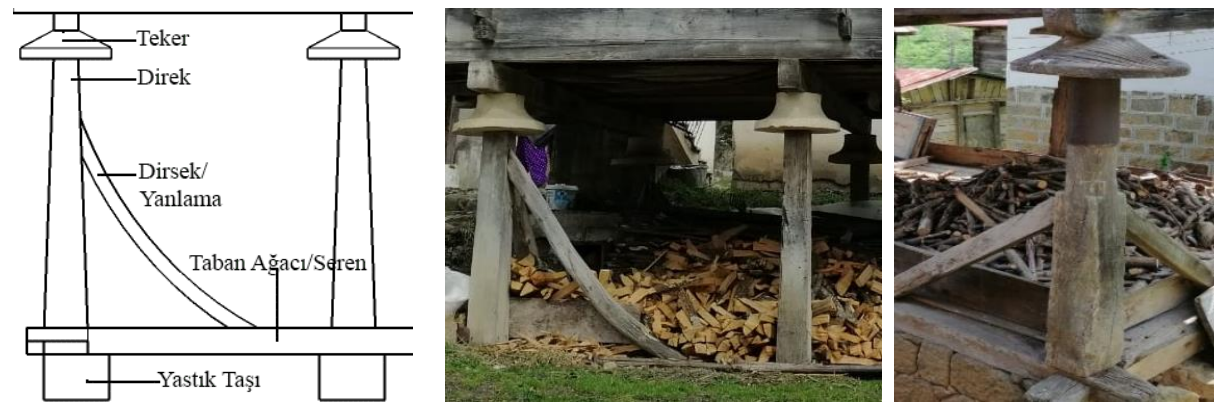

Şekil 8. Serender direği örnekleri

Direkler üzerine kurulan serenderlerin alt kısmı tamamıyla boştur. Bu boşluk sayesinde zeminde süreklilik sağlanır, saklanan yiyeceklerin nem ve su birikintisinden zarar görmesi engellenir. Her bir direğin başına ağaç veya taştan yapılmış dairesel, genellikle konik olan bir tekerlek monte edilir. Bu tekerleklerin işlevi serendere fare ve diğer zararlıların çıkmasını engellemektir (Şekil 9).
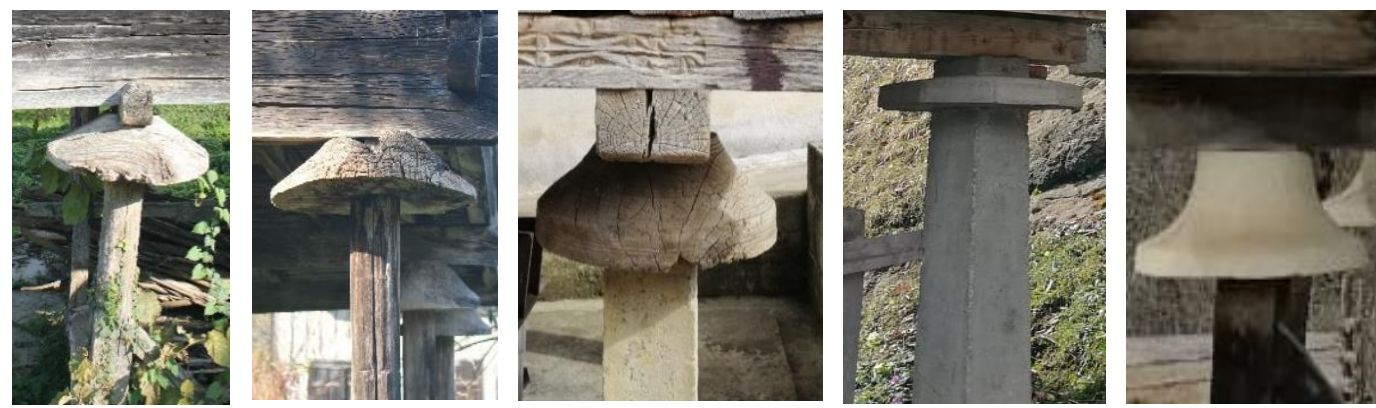

Şekil 9. Serender teker örnekleri

Depolama alanı yerden yüksek olan serenderlere çıkmak için seyyar ya da zemine değmeyen (zeminden $50-90 \mathrm{~cm}$ yüksekte duran) bir merdiven kullanılır. Gerekli durumda serendere monte edilen taşınabilir bir merdiven ile yukarı çıkılmaktadır (Şekil 10).
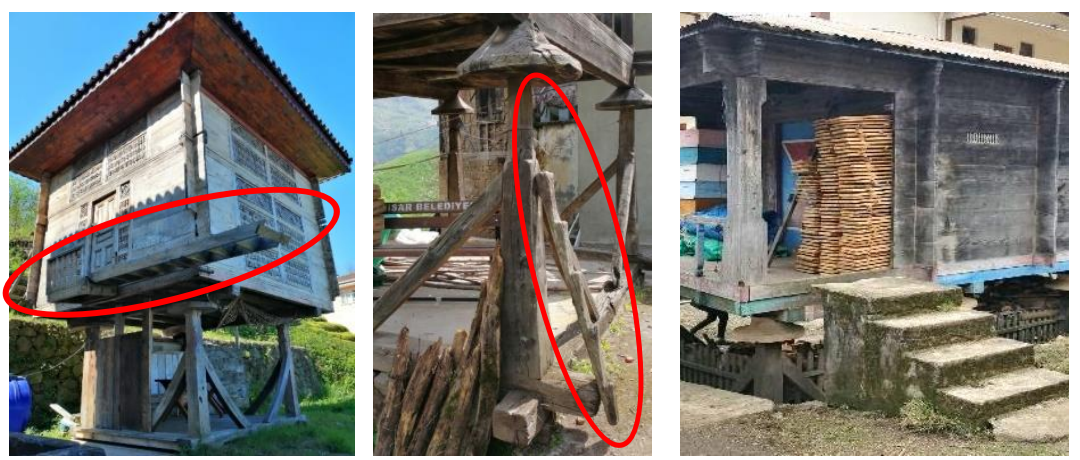

Şekil 10. Serender merdiven örnekleri

Serenderlerin kapalı ve yarı açık alanındaki döşemelerinde kullanılan malzeme ahşaptır, fakat uygulamaları farklı olabilmektedir. Serenderin en önemli bölümü olan ambarda hem hava sirkülasyonu sağlanarak mısırın kuruması hem de dövülen mısır tanelerinin alt kısma aktarıması için genellikle ızgaralı döşeme kullanılırken, yarı açık alan olan çardağın havalandırmaya ihtiyacı olmadığından döşemesinde ızgara bulunmamaktadır. Izgaralı döşemeli ambarlarda içeri adım atıldığında en fazla ayak basılan ve yıpranan ilk 40-50 cm lik biçilmiş ağaçtan yapılan tahta ile döşelidir. Geri kalan kısmı fındık ağacı gibi dayanıkı çalılarla örülmektedir (Şekil 11). 

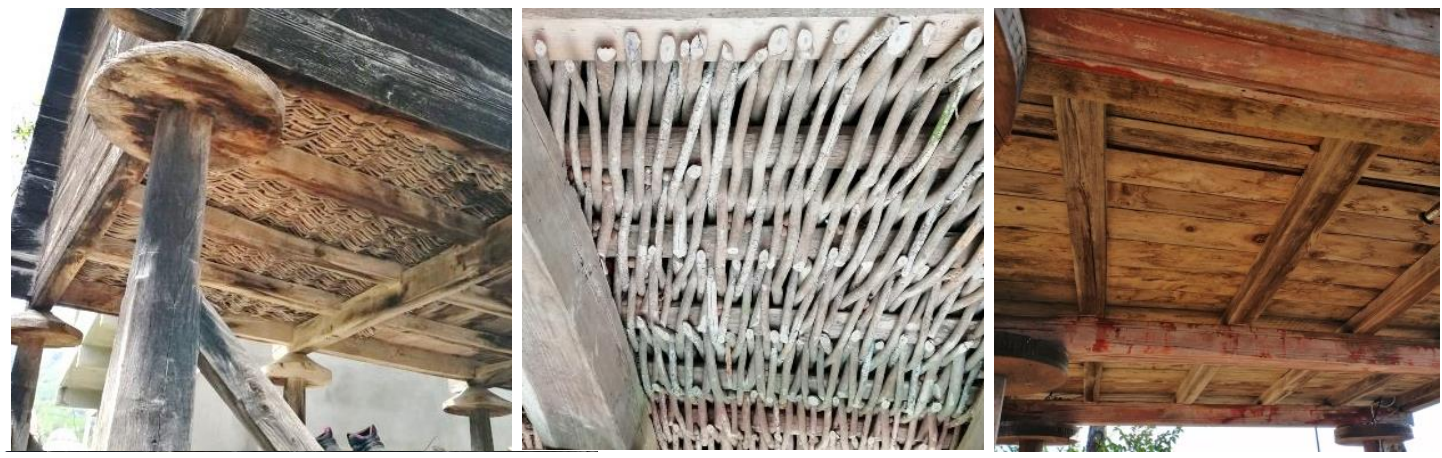

Şekil 11. Serender döşeme örnekleri

Serender duvarlarının oluşturulmasında dikmeli ve dikmesiz olmak üzere iki teknik kullanılır. Dikmesiz serenderlerin duvarları "boğaz", "geçme" tekniğiyle veya her iki tekniğin birlikte kullanılmasıyla oluşturulur. Yaklaşık $5 \mathrm{~cm}$ kalınlığına, 20- $40 \mathrm{~cm}$ genişliğe sahip tahtalar yatay olarak yerleştirilir. Boğaz sistemde tahta uçları kertilir ve taraklama yoluyla birbirilerine bağlanır. Geçme sistemde ise soldan ve sağdan gelen tahtalar serenderin köşelerinde ve bölme yerlerinde yer alan kolonlara geçirilir (Demir, 2004, Yılmaz, 2007) (Şekil 12).
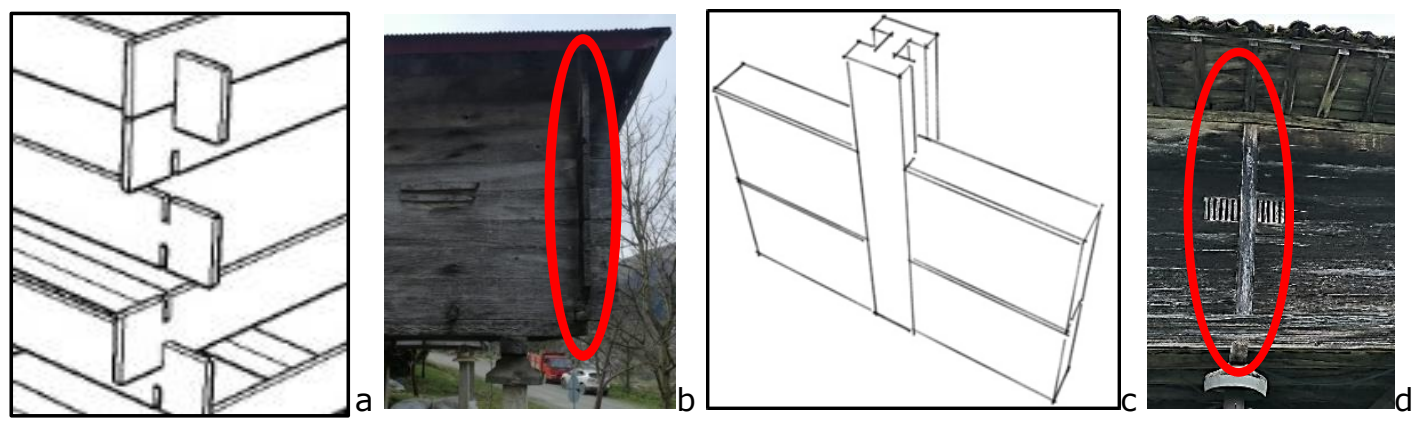

Şekil 12. Serender duvarında boğaz tekniği örneği $(a, b)$ ile geçme tekniği örneği $(c, d)$

Serenderin çatısının ilk kısmını dikmelerin veya yatay tahtaların üzerine atılan serender bağı denilen taban aşığı oluşturmaktadır. Serender çatıları, omuz çatı ve kırma çatı olmak üzere iki çeşittir. Kırma çatı, genellikle sekiz direkli serenderlere yapılmaktadır. Serenderin her köşesinden gelen çatı ağaçları, serenderin en üst noktasında yatay olarak bulunan, uzunluğu 1-3 m arasında değişen mahya aşığına çakılmaktadır. Omuz çatı, dört veya altı direk üzerine yapılmış olanlar serenderler de görülmektedir. Bu tür çatılarda mahya aşığı bulunmamaktadır. Bu durumda çatının zirvesi tek noktada toplanmaktadır.

Çatının üzerine çakılan mertek görevi gören ağaçların boyu serenderin gövdesinden $50-90 \mathrm{~cm}$ daha uzundur. Saçak denilen bu artırmanın uçlarına dört tarafını çevreleyen $2 \times 8 \mathrm{~cm}$ boyutunda saçak bağları çakılmaktadır. Saçak bağları üst örtüsünün kaymasını ve karın aynı anda akmasını önlemekte, serenderi derli toplu göstermektedir. Çatı öğesi eskiden karatahta veya hartama ile örtülürken günümüzde aynı amaçla sac veya kiremit kullanılmaktadır (Şekil 13) (Demir, 2004).

Evin sahibinin zenginliğini de simgelediği için özel bir yapı olan serender özenle süslenmektedir. Serenderin ön cephesindeki kirişler, kapısı ve ambar kısmının havalandırma delikleri ahşap oyma ve ajur (delgi) tekniğinde yapılmaktadır (Şekil 14). Geometrik ve bitkisel motiflerden oluşan bordürler ve panolara yer verilmektedir. Motifler arasında çarkıfelek, ayyıldız gibi sembolik örnekler de bulunmaktadır (Karpuz, 1999). 

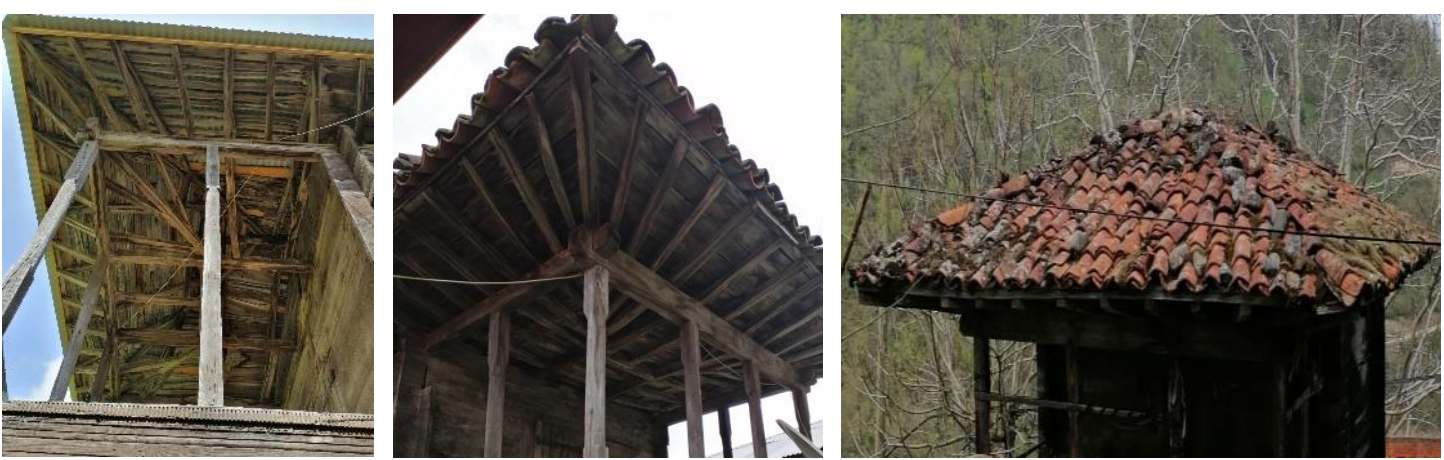

Şekil 13. Serender çatı örnekleri
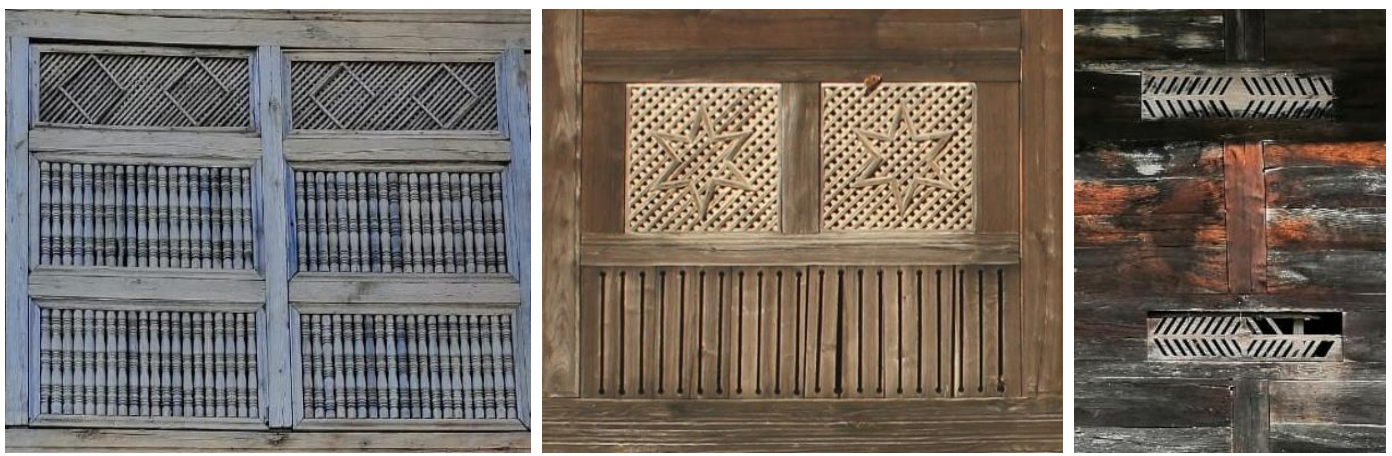

Şekil 14. Serender havalandırma ve süsleme detayı örnekleri

Serenderlerin temelden çatıya kadar yapı sisteminin tümünün çivi ve benzeri madeni eleman kullanılmadan geçme detaylarla çözümlenmiş olduğu söylenebilir. Yine de yöredeki ustalar tarafından yapılan döğme kilit ve menteşelerin kapılarda, döğme çivilerin ise kilit, menteşe ve çatı ile ilgili tespit işlerinde kullanıldığı görülmektedir. Bu ayrıcalıkların dışında detayların tümünün geçmelerle çözümlenmesi, yapı sistemine sökülüp takılabilme özelliği kazandırır. Yapı elemanları önceden işlenip hazırlanması inşa sırasında kolaylık sağlar. Bitmiş bir serender bir süre sonra istenirse sökülüp başka bir yere yeniden kurulabilir (Eruzun, 1977).

\section{MATERYAL VE YÖNTEM}

Çalışmada, kırsal yerleşmelerdeki kültürel mirasa sahip çıkmak, serenderlerin varlığını korumak, gelecek nesillere yerel mimari konusunda referans olmak adına Doğu Karadeniz Bölgesi'nde yer alan Trabzon ilinin Sürmene, Tonya ve Arakıı ilçeleri kırsal alanlarındaki geleneksel yapı türü olan serenderler incelenmiştir. Alan seçiminde geleneksel kültür mirası serenderlere günümüzde sık rastlanan ilçelerden oluşmasına dikkat edilmiştir (Şekil 15).

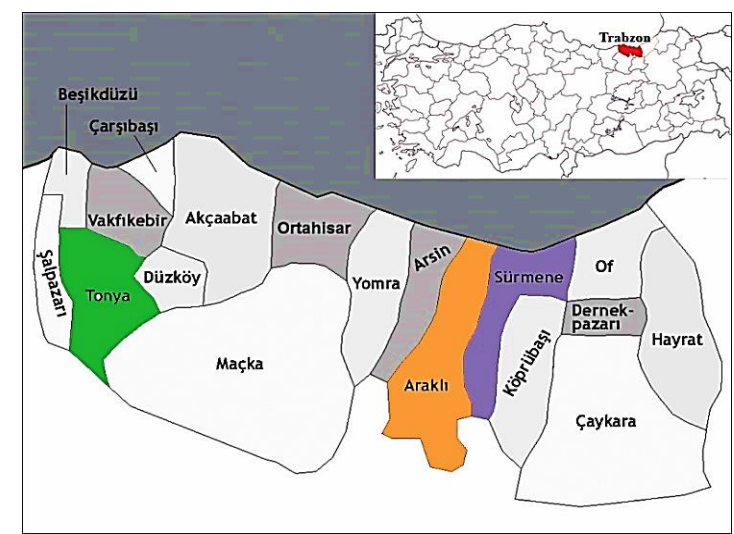

Şekil 15. Çalışmanın alanı 
Oldukça engebeli bir araziye sahip Doğu Karadeniz Bölgesi'nde sahil şeridinden hemen yükselmeye başlayan sıra dağlar doğu-batı yönünde denize paralel uzanarak bölge ikliminin önemli belirleyicisi olmuştur. Bölgede 'ılıman-nemli' iklim tipi özellikleri görülmektedir. Kıyı şeridinden başlayan dağlar, kuzeyden ve batıdan gelen hava kütlelerinin iç bölgeye geçmesine engel oluşturur. Bu nedenle yükselirken soğuyan hava, barındırdığı nemi bölgenin kuzey yamaçlarına bırakır. Bu bölge, Türkiye'nin en çok yağış alan bölgesidir. Bölgede bol yağış, deniz etkisi ve bitki örtüsünün sıklığı nedeniyle nemlilik oranı normal değerlerin üzerindedir (Sümerkan, 2008, Sümerkan, 2019). Çalışmanın yürütüldüğü Trabzon ili iklim, topoğrafya ve bitki örtüsü açısından Doğu Karadeniz Bölgesi'nin genel karakteristik özelliklerinin en belirgin şekilde görülen yerleşimlerindendir.

Araştırmanın başında geleneksel mimari, serenderler, ekoloji ve sürdürülebilirlik konusunda geniş bir literatür taraması yapılmıştır. Sürdürülebilirliğin ekolojik, ekonomik ve sosyal-kültürel boyutlarından çalışma kapsamında ekolojik sürdürülebilirlik konusu ele alınmıştır. Sürmene, Tonya ve Araklı ilçelerinde tespit edilen serenderlerin hangi açılardan ekolojik ve sürdürülebilir olduğunu saptamak için kontrol listeleri hazırlanmıştır. Kontrol listeleri, literatürde yer alan ekolojik ve sürdürülebilir tasarım kriterlerine göre oluşturulmuştur. Literatürdeki kriteler derlenip aşağıda maddeler halinde sunulmuştur:

Ekolojik tasarım kriterleri (Yeang, 2012; İnanç, 2010; Aktuna, 2007; Özek ve Kısa Ovalı, 2007):

- Binanın Konumu: Ekolojik tasarımın önemli bir ölçütü, çevresel verilere bağlı olarak binanın konumlandırılması ve yönlendirilmesidir. İklim kontrolünü ve hava kirliliğini önlemede; arazinin yönü, eğimi, konumu ve örtü verileri önemli faktörlerdendir.

- Binanın Yönlenmesi: Güneşin ısısından ve rüzgarın serinliğinden yararlanmak için yön önemli bir faktördür. Ülkemizin de içinde yer aldığı iklim kuşağında ısı gereksinimi önceliklidir. Bina yönlenmesi güneşten ve rüzgardan büyük ölçüde yararlanmada etkili bir tasarım öğesidir.

- Bina Formu: Bina yüksekliği, çatı türü ve eğimi, cephe eğimi gibi bina ile ilgili değişkenler bina formu olarak açıklanır. Bu değişkenler yapının dış atmosferik, iç mekan konfor koşullarının düzenlenmesinde farklı etkilere sahiptir.

- Mekansal Organizasyon: Yapının kendi içinde işlevsel gereksinimleri doğrultusunda mekanlara ayrılması, bu mekanların da ISı gereksinim ve hiyerarşine göre düzenlenmesi sağlıklı bir mekan organizasyonunun oluşturulması yönünden önemlidir.

- Malzeme: Bina yapımında kullanılan malzemeler çevreye uyumlu ve doğal olmalıdır. İmalat ve taşıma sürecinde daha az enerji gereken malzemeler tercih edilmelidir. Binanın imalat, kullanım ve yıkım evrelerinde doğaya asgari zarar veren, yıkılmasına müteakip yeniden kullanılabilir malzemeler tercih edilmelidir.

- Yapı Kabuğu: Yapı içi ile dışını birbirinden ayıran yapı kabuğu, enerjinin en az seviyede kullanılmasıyla hem çevre problemlerini önlemek hem de ısısal konfor düzeyine ulaşmak için en etkili hususlardan bir tanesidir.

- Tükenmeyen Enerji Kaynaklarının Kullanımı: Bina tasarımında düşük enerji tüketimi ve ucuz işletim dikkat edilmesi gereken önemli hususlardandır. İşlevsel ve strüktürel gereklerin yanı sıra enerji kayıplarının en aza indirilmesi ve tükenmeyen enerji kaynaklarından yararlanılması gittikçe önem kazanmaktadır.

- Sıhhı Tesisat Elemanları: Dünya genelinde giderek azalan temiz su kaynaklarının korunması, toplanması, yeniden kullanımı, yapılarda oluşan atıkların arıtılması ve yeniden kullanılabilir olanların kazanılması, çöplerin geri dönüşüme tabii tutularak hammadde olacak şekilde ayrıştırılması önemli ekolojik tasarım kriterlerindendir.

Sürdürülebilir tasarım kriterleri (Lakot Alemdağ ve Al Şensoy, 2018; Sev, 2009; Ford, 2007; Yudelson 2007):

- Yapı alanının etkin kullanımı: Sürdürülebilir yapılar bulunduğu çevre ve iklime uygun tasarıma sahip olmalıdır. Birçok bölgede arazinin verimli kullanılmaması, tarım alanları yerine yapıların inşa edilmesi, yapı sektörünün doğal ve ekolojik hayata olan negatif etkilerindendir. Arazi seçimi ve analizinde; arazinin doğal sınırlarının 
korunması, iklimsel ve topografik özellikler, altyapı çalışmaları, ulaşım ağlarından etkin bir şekilde yararlanma ve doğal ekolojik çevreye minimum etkide bulunmak gibi kriterlerin göz önünde bulundurulması gerekmektedir.

- Atık azaltma: Binalarda kullanılan her türlü malzemenin ömrü tamamlandığında bir takım işlemlerden geçirilerek geri dönüştürülmesi ve yeniden kullanılacak hale getirilmesi sürdürebilirlik sürecinde enerji etkinliği ve çevre korunması bakımından önemlidir.

- Su korunumu: Suyun kullanılmadan önce arıtılması, bina içinde dağıtılması ve geri toplanarak tekrar arıtılması için enerji harcanmaktadır. Yağmur suyunun toplanması, kullanım suyunun arıtılarak değerlendirilmesi, yerinde atık su arıtımı, bulanık su yönetimi, çevre düzenlenmesi, yüksek verimli sulama, biyofiltrasyon kullanımı su tasarrufuna katkı sağlamaktadır.

- Enerji Korunumu: Isı yalıtımı, enerji ihtiyacının azaltılması, pasif ve aktif enerji sistemlerinin kullanılmasıdır. Fotovoltaik paneller, pasif güneş stratejileri, dış güneş gölgeleri/rüzgar türbinleri, yüksek performanslı yapı kabuğu, ıSı pompalarıyla birleştirilmiş jeotermal zemin kaynağı, termal kütle, bilgisayar kontrollü yüksek verimli sistemler, yeşil çatılar, serin çatılar yapılarda enerji korunumunda etkin rol oynamaktadır.

- İç mekân hava kalitesi: Isı farklılıklarının oluşturduğu hava kalitesiyle, taze havanın dışarıdan yapı içine girmesi, aynı oranda kirli havanın dışarıya aktarılması olarak ifade edilen doğal havalandırma iç mekân hava kalitesini önemli belirleyicilerindendir.

- Geri dönüştürülmüş ve yeşil malzemeler: Şantiye sahasındaki tüm yapıların geri dönüşümü, içeriği, yapıda kullanılan malzemelerin geri dönüşümlü içeriği, sertifikalı yeşil bina malzemesi gibi etkenler olarak açıklanabilir. Sürdürülebilir tasarım yaklaşımı olarak projelerde düşük maliyetli yerel ve bölgesel malzeme kullanılması çevresel etkileri azaltarak kullanıcı sağlığını korumaya yardımcı olmaktadır.

- Doğal Aydınlatma ve Görsel Konfor: Gün ışığı ile iç mekânlarda gerekli düzeyde aydınlatmanın sağlanması, kullanıc performansı ve mutluluğunun artması bakımından önemli bir etkendir.

Yukarıda yer alan ekolojik ve sürdürülebilir tasarım kriterleri referans alınarak serenderlerin analizlerinde kullanılmak üzere; planlama, yapı elemanlarının tasarımı, enerji, havalandırma, aydınlatma, malzeme, ekosistemi koruma ve konfor gibi yedi ana bölümden meydana gelen bir kontrol listesi oluşturulmuştur. Kontrol listesinde yer alan her bir bölümün alt başlıkları ise aşağıda yer almaktadır:

- Planlama: Direk sayısı, çardak konumu, bina formu, yönlenme, teker malzemesi, esnek mekân kullanımı.

- Yapı Elemanlarının Tasarımı: Geleneksel strüktür sistem kullanımı, ısı ses yangın yalıtımı, güneş kontrol elemanlarının kullanımı.

- Enerji: Yenilebilir enerji kaynaklarının kullanımı, işgücünün hafifliği.

- Havalandırma: Doğal havalandırma, yapay havalandırma.

- Aydınlatma: Doğal aydınlatma, yapay aydınlatma.

- Malzeme: Doğal malzeme kullanımı, yerel malzeme kullanımı, daha az bakım gerektiren malzeme kullanımı, geri dönüştürülmüş malzeme kullanımı.

- Ekosistemi Koruma ve Konfor: Topografyaya uygun şekilde konumlanması, doğa ile uyumlu, iklim şartlarına uygunluğu, tasarımda doğal konturları korumak, işitsel konforun sağlanması.

Alan çalışmasında üç ilçede ele alınan serenderlerin röleveleri çıkarılmış, fotoğrafları çekilmiş ve yöre halkı ile görüşmeler yapılmıştır. Ayrıca alan çalışmasının yürütüldüğü Sürmene (Aksu Mahallesi), Tonya (Yakçukur Kalınçam ve Çayıriçi Mahallesi), Araklı (Pervane Mahallesi) ilçelerindeki serenderlerin bulunduğu yer, komşuluk grubu, kullanım durumu, plan tipi, direk sayısı, yarı açık alan ve kapalı alan bilgilerini, plan, cephe gibi mimari anlatım ve görsellerini içeren kimlik kartları oluşturulmuştur. Aşağıda Şekil 16'da çalışmada izlenen yöntemi gösteren iş akış şeması yer almaktadır. 


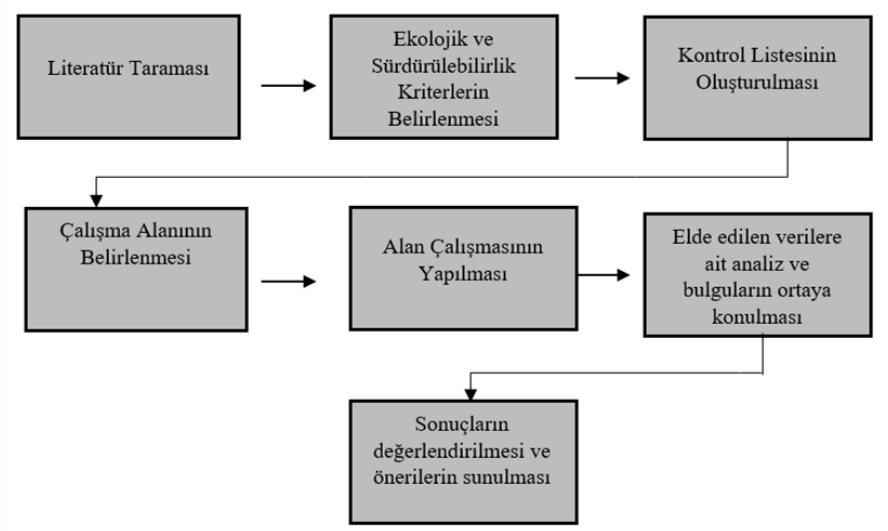

Şekil 16. Çalışmanın iş akış şeması

Doğu Karadeniz kültür mirası öğelerinden olan serenderleri, ekolojik ve sürdürülebilir tasarım açısından irdelemek için belirlenen her ilçeden 5, toplamda 15 adet serender seçilerek yerinde tespit yöntemiyle incelenmiştir. Çalışmanın materyalini oluşturan serenderlerin kimlik bilgileri Tablo 1'de yer almaktadır.

Tablo 1. Çalışmada incelenen serenderlerin kimlik bilgileri ve görselleri

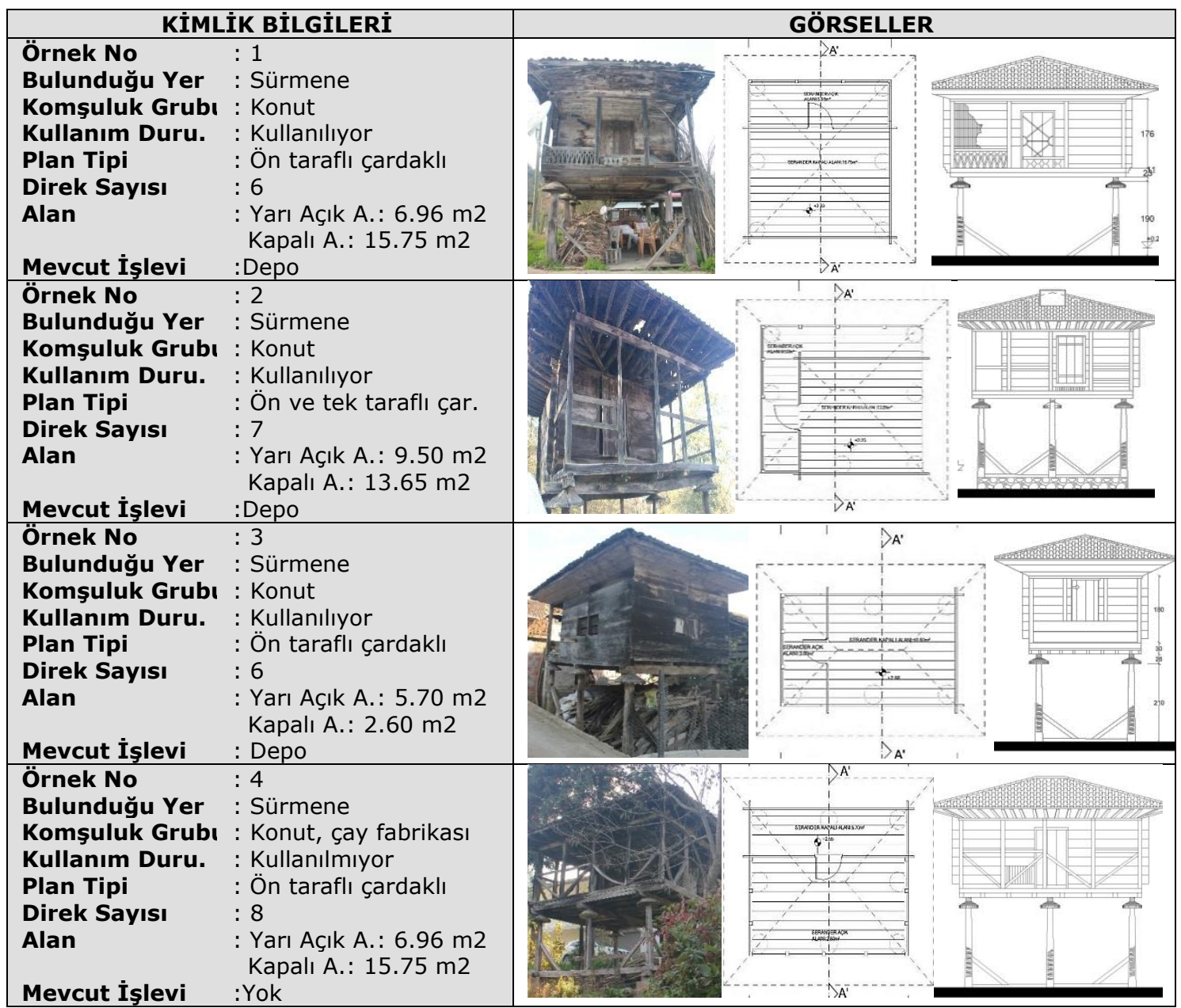


Tablo 1. Çalışmada incelenen serenderlerin kimlik bilgileri ve görselleri

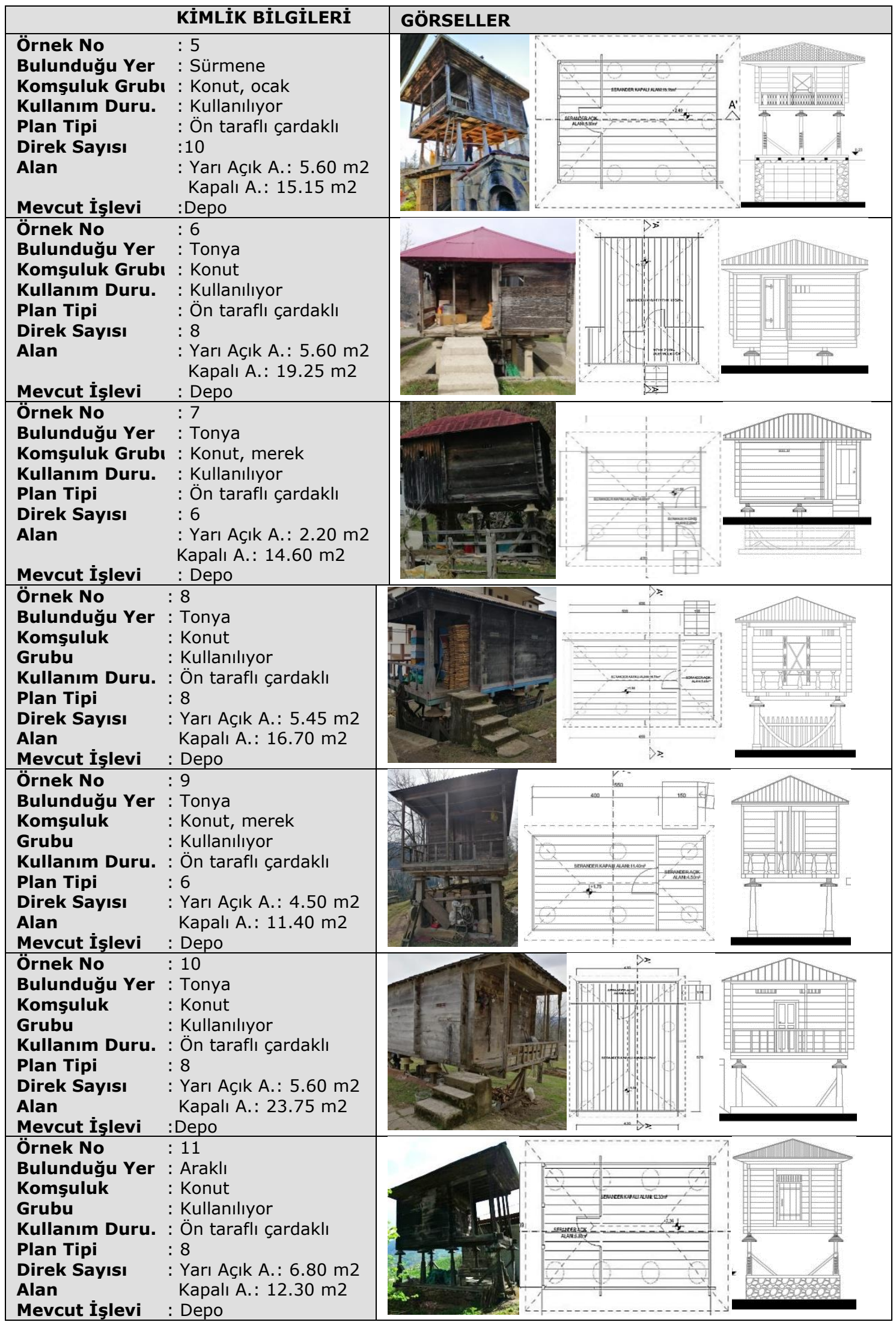


Tablo 1. Çalışmada incelenen serenderlerin kimlik bilgileri ve görselleri

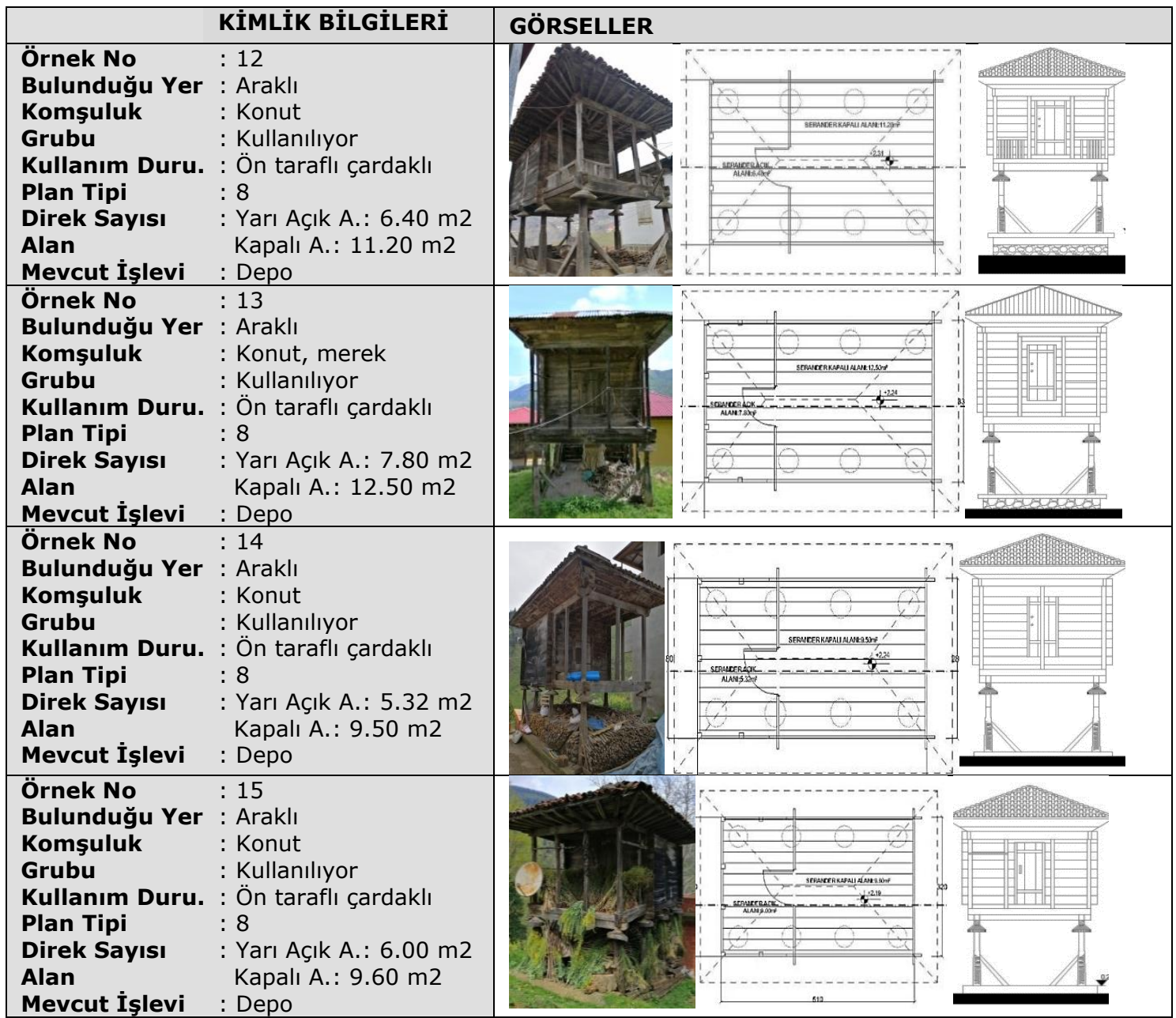

\section{BULGULAR ve DEĞERLENDİRME}

Hazırlanan ekolojik ve sürdürülebilirlik kontrol listelerine göre yapılan serenderlerin analizleri sonucu elde edilen veriler Tablo 2'de yer almaktadır. Tablo 2'de bütün serenderlerin ekolojik ve sürdürülebilirlik kriter değerlendirmeleri serenderler arası karşılaştırma yapabilmek, genel sonucu görebilmek için bir arada sunulmuştur.

Çalışmadaki serenderlerin ekolojik ve sürdürülebilirlik açısından değerlendirildiği Tablo 2'de yer alan veriler incelendiğinde serenderlerin çoğunlukla 6-8 adet direğe sahip orta büyüklükteki serenderler olduğu saptanmıştır. Kolon sayısına bağlı olarak formları da dikdörtgendir. Genellikle ön tarafında tek çardak bulunan örneklerin yönlenmesi hakim rüzgar dikkate alınarak kuzey-güney yönündedir. Rüzgar, güneş, yağmur vb. iklimsel faktörler yapıların yönlenmesindeki önemli etkenlerdendir. Bu bağlamda çalışma alanındaki hakim rüzgar yönü, güneşin doğuşu ve batışı dikkati alındığında serenderlerin bölgedeki yoğun neme karşı işlevini etkili bir şekilde yerine getirebilmesi için kuzey-güney doğrultusunda konumlandığı düşünülmektedir. Esnek mekan kullanımına sahip serenderler depo işlevinin dışında oturma, yatma vb. başka amaçlarla da kullanılabilir. Serenderlerin iç mekanı gerekli durumlarda ahşap bölücü duvarlar kullanarak farklı kullanım alanlarına dönüşebilmektedir. Genellikle ahşap dikmelerin üzerinde yer alan, bir kattan oluşan serenderler arazinin eğimli olduğu durumlarda kolonların altında kot farkından yararlanarak bir kat daha oluşturulmuş ve bu alan çoğunlukla depo olarak kullanılmaktadır (Örnek 5, 12, 15).

İncelenen serenderlerin yapı elemanlarının tasarımına bakıldığında tümünde geleneksel strüktür sistemi olan ahşap yığma ve ahşap karkas sisteminin karışık şekilde kullanıldığı 
görülmektedir. Fakat zaman içerisinde serenderlerin ahşap direklerinin fiziksel koşullardan zarar görmesi nedeniyle taşıyıcılık özelliğini yitirdiğini düşünen kullanıcıların ahşap direkleri betonarme kolonlarla değiştirdikleri saptanmıştır. Ayrıca incelemeye dahil olmayan çalışma alanındaki bazı serenderler yerden yükseltilmiş direkler üzerine değil betonarme veya tuğla duvar üzerine inşa edilip alt kısmın depo olarak kullanıldığı tespit edilmiştir. Diğer taraftan daha çok depo amacıyla kullanılması nedeniyle ısı, ses, yangın yalıtımı ve güneş kontrol elemanlarının kullanımı ile ilgili hiçbir serenderde veri tespiti yapılamamıştır.

Enerji kriterine göre serenderler irdelendiğinde tamamında yerel malzeme ve geleneksel yapım sistemleri kullanımının getirdiği iş gücünün hafifliğinden söz edilebilirken yenilebilir enerji kaynağı kullanımı ile ilgili bir bulguya rastlanılmamıştır.

Aydınlatma ve havalandırma açısından serenderlere bakıldığında serenderlerin tamamında doğal havalandırma ve aydınlatmanın olduğu, sadece örnek 14 'te doğal aydınlatmanın yanında yapay aydınlatmanın da bulunduğu saptanmıştır. Serenderlerde bulunan havalandırma delikleri, hem süsleme hem de doğal havalandırma ve aydınlatma öğesidir. Ayrıca bazı serenderler çatı fenerleri, pencereler bulunmaktadır. Doğal aydınlatma ve havalandırma elemanlarının kullanılması serenderin içerisinde saklanan ürünlerin yapay herhangi bir enerji harcamadan havalanmasını, kurumasını ve taze kalmasını sağlamaktadır.

Tablo 2. Serenderlerin ekolojik ve sürdürülebilirlik kriterleri kontrol listesi

\begin{tabular}{|c|c|c|c|c|c|c|c|c|c|c|c|c|c|c|c|c|c|}
\hline EKOL & $\begin{array}{r}\text { OJİK VE SÜR } \\
\text { KRİTE }\end{array}$ & $\begin{array}{l}\text { ÜRÜLEBİLİRLİK } \\
\text { LERİ }\end{array}$ & 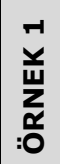 & $\begin{array}{l}N \\
\text { y. } \\
\text { un } \\
\underline{\alpha} \\
: 0\end{array}$ & 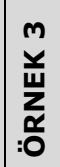 & $\begin{array}{l}\mathbf{y} \\
\text { ü } \\
z \\
\text { : } \\
0\end{array}$ & $\begin{array}{l}\text { n } \\
\text { un } \\
z \\
\text { : } \\
: 0\end{array}$ & $\begin{array}{l}0 \\
y \\
u \\
z \\
\alpha \\
: 0\end{array}$ & $\begin{array}{l}\mathbf{N} \\
\underline{u} \\
\mathbf{Z} \\
\tilde{\alpha} \\
: 0\end{array}$ & $\begin{array}{l}\infty \\
\text { 前 } \\
\underline{Z} \\
\text { : } \\
0\end{array}$ & 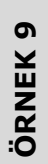 & 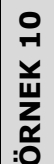 & 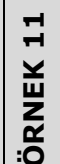 & 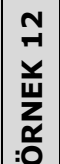 & 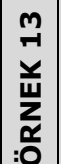 & 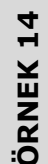 & $\begin{array}{l}\text { n } \\
\text { r } \\
\text { 前 } \\
\text { zo } \\
: 0\end{array}$ \\
\hline & & 4 & & & & & & & & & & & & & & & \\
\hline & Direk Sayısı & $6-8$ & $\sqrt{ }$ & $\sqrt{ }$ & $\sqrt{ }$ & $\sqrt{ }$ & & $\sqrt{ }$ & $\sqrt{ }$ & $\sqrt{ }$ & $\sqrt{ }$ & $\sqrt{ }$ & $\sqrt{ }$ & $\sqrt{ }$ & $\sqrt{ }$ & $\sqrt{ }$ & $\sqrt{ }$ \\
\hline & & $10-12$ & & & & & $\sqrt{ }$ & & & & & & & & & & \\
\hline & & Ön taraflı & $\sqrt{ }$ & & $\sqrt{ }$ & $\sqrt{ }$ & $\sqrt{ }$ & $\sqrt{ }$ & $\sqrt{ }$ & $\sqrt{ }$ & $\sqrt{ }$ & $\sqrt{ }$ & $\sqrt{ }$ & $\sqrt{ }$ & $\sqrt{ }$ & $\sqrt{ }$ & $\sqrt{ }$ \\
\hline 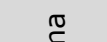 & Çardak & Ön ve tek taraflı & & $\sqrt{ }$ & & & & & & & & & & & & & \\
\hline 芫 & Konumu & Ön ve iki taraflı & & & & & & & & & & & & & & & \\
\hline$\overline{\frac{\pi}{\pi}}$ & & Dört taraflı & & & & & & & & & & & & & & & \\
\hline & & Kare & & & & & & & & & & & & & & & \\
\hline & Bina Formu & Dikdörtgen & $\sqrt{ }$ & $\sqrt{ }$ & $\sqrt{ }$ & $\sqrt{ }$ & $\sqrt{ }$ & $\sqrt{ }$ & $\sqrt{ }$ & $\sqrt{ }$ & $\sqrt{ }$ & $\sqrt{ }$ & $\sqrt{ }$ & $\sqrt{ }$ & $\sqrt{ }$ & $\sqrt{ }$ & $\sqrt{ }$ \\
\hline & & Kuzey- Güney & & $\sqrt{ }$ & $\sqrt{ }$ & & $\sqrt{ }$ & & $\sqrt{ }$ & $\sqrt{ }$ & $\sqrt{ }$ & $\sqrt{ }$ & $\sqrt{ }$ & $\sqrt{ }$ & $\sqrt{ }$ & $\sqrt{ }$ & $\sqrt{ }$ \\
\hline & Yonlenme & Doğu- Batı & $\sqrt{ }$ & & & $\sqrt{ }$ & & $\sqrt{ }$ & & & & & & & & & \\
\hline & Esnek mekar & kullanımı & $\sqrt{ }$ & $\sqrt{ }$ & $\sqrt{ }$ & $\sqrt{ }$ & $\sqrt{ }$ & $\sqrt{ }$ & $\sqrt{ }$ & $\sqrt{ }$ & $\sqrt{ }$ & $\sqrt{ }$ & $\sqrt{ }$ & $\sqrt{ }$ & $\sqrt{ }$ & $\sqrt{ }$ & $\sqrt{ }$ \\
\hline घं $\bar{E}$ & $\begin{array}{l}\text { Geleneksel S } \\
\text { kullanımı }\end{array}$ & üktür sistem & $\sqrt{ }$ & $\sqrt{ }$ & $\sqrt{ }$ & $\sqrt{ }$ & $\sqrt{ }$ & $\sqrt{ }$ & $\sqrt{ }$ & $\sqrt{ }$ & $\sqrt{ }$ & $\sqrt{ }$ & $\sqrt{ }$ & $\sqrt{ }$ & $\sqrt{ }$ & $\sqrt{ }$ & $\sqrt{ }$ \\
\hline$\overline{0} \overline{0} \frac{5}{0}$ & Isı, ses, yanc & 7 yalıtımı & & & & & & & & & & & & & & & \\
\hline$\stackrel{0}{\pi}$ & $\begin{array}{l}\begin{array}{l}\text { Güneş kontrc } \\
\text { kullanımı }\end{array} \\
\end{array}$ & elemanlarının & & & & & & & & & & & & & & & \\
\hline 要 & $\begin{array}{l}\text { Yenilebilir en } \\
\text { kullanımı } \\
\end{array}$ & ji kaynaklarının & & & & & & & & & & & & & & & \\
\hline & İş gücünün $h$ & fifliği & $\sqrt{ }$ & $\sqrt{ }$ & $\sqrt{ }$ & $\sqrt{ }$ & $\sqrt{ }$ & $\sqrt{ }$ & $\sqrt{ }$ & $\sqrt{ }$ & $\sqrt{ }$ & $\sqrt{ }$ & $\sqrt{ }$ & $\sqrt{ }$ & $\sqrt{ }$ & $\sqrt{ }$ & $\sqrt{ }$ \\
\hline & Doğal havala & dırma & $\sqrt{ }$ & $\sqrt{ }$ & $\sqrt{ }$ & $\sqrt{ }$ & $\sqrt{ }$ & $\sqrt{ }$ & $\sqrt{ }$ & $\sqrt{ }$ & $\sqrt{ }$ & $\sqrt{ }$ & $\sqrt{ }$ & $\sqrt{ }$ & $\sqrt{1}$ & $\sqrt{ }$ & $\sqrt{ }$ \\
\hline$\sqsubseteq \frac{0}{7}$ & Yapay havala & dırma & & & & & & & & & & & & & & & \\
\hline 文而 & Doğal aydınle & $\mathrm{ma}$ & $\sqrt{ }$ & $\sqrt{ }$ & $\sqrt{ }$ & $\sqrt{ }$ & $\sqrt{ }$ & $\sqrt{ }$ & $\sqrt{ }$ & $\sqrt{ }$ & $\sqrt{ }$ & $\sqrt{ }$ & $\sqrt{ }$ & $\sqrt{ }$ & $\sqrt{ }$ & $\sqrt{ }$ & $\sqrt{ }$ \\
\hline & Yapay aydınl & $\mathrm{ma}$ & & & & & & & & & & & & & & $\sqrt{ }$ & \\
\hline & Doğal malzer & e kullanımı & $\sqrt{ }$ & $\sqrt{ }$ & $\sqrt{ }$ & $\sqrt{ }$ & $\sqrt{ }$ & $\sqrt{ }$ & $\sqrt{ }$ & $\sqrt{ }$ & $\sqrt{ }$ & $\sqrt{ }$ & $\sqrt{ }$ & $\sqrt{ }$ & $\sqrt{ }$ & $\sqrt{ }$ & $\sqrt{ }$ \\
\hline & Yerel malzen & kullanımı & $\sqrt{ }$ & $\sqrt{ }$ & $\sqrt{ }$ & $\sqrt{ }$ & $\sqrt{ }$ & $\sqrt{ }$ & $\sqrt{ }$ & $\sqrt{ }$ & $\sqrt{ }$ & $\sqrt{ }$ & $\sqrt{ }$ & $\sqrt{ }$ & $\sqrt{ }$ & $\sqrt{ }$ & $\sqrt{ }$ \\
\hline 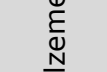 & $\begin{array}{l}\text { Daha az bak } \\
\text { malzeme kul }\end{array}$ & $\begin{array}{l}\mathrm{n} \text { gerektiren } \\
\text { nımı }\end{array}$ & $\sqrt{ }$ & $\sqrt{ }$ & $\sqrt{ }$ & $\sqrt{ }$ & $\sqrt{ }$ & $\sqrt{ }$ & $\sqrt{ }$ & $\sqrt{ }$ & $\sqrt{ }$ & $\sqrt{ }$ & $\sqrt{ }$ & $\sqrt{ }$ & $\sqrt{ }$ & $\sqrt{ }$ & $\sqrt{ }$ \\
\hline$\sum^{\bar{\pi}}$ & Geri dönüştü & il. malz. kullanımı & $\sqrt{ }$ & $\sqrt{ }$ & $\sqrt{ }$ & $\sqrt{ }$ & $\sqrt{ }$ & $\sqrt{ }$ & $\sqrt{ }$ & $\sqrt{ }$ & $\sqrt{ }$ & $\sqrt{ }$ & $\sqrt{ }$ & $\sqrt{ }$ & $\sqrt{ }$ & $\sqrt{ }$ & $\sqrt{ }$ \\
\hline & Teker & Ahşap & $\sqrt{ }$ & $\sqrt{ }$ & $\sqrt{ }$ & $\sqrt{ }$ & $\sqrt{ }$ & & & & & & $\sqrt{ }$ & $\sqrt{ }$ & $\sqrt{ }$ & $\sqrt{ }$ & $\sqrt{ }$ \\
\hline & Malzemesi & Taş & & & & & & $\sqrt{ }$ & $\sqrt{ }$ & $\sqrt{ }$ & $\sqrt{ }$ & $\sqrt{ }$ & & & & & \\
\hline $\bar{\varepsilon} \stackrel{0}{>}$ & $\begin{array}{l}\text { Topoğrafyay } \\
\text { konumlanma }\end{array}$ & uygun şekilde & $\sqrt{ }$ & $\sqrt{ }$ & $\sqrt{ }$ & $\sqrt{ }$ & $\sqrt{ }$ & $\sqrt{ }$ & $\sqrt{ }$ & $\sqrt{ }$ & $\sqrt{ }$ & $\sqrt{ }$ & $\sqrt{ }$ & $\sqrt{ }$ & $\sqrt{ }$ & $\sqrt{ }$ & $\sqrt{ }$ \\
\hline 㫕 & \begin{tabular}{|l|} 
Doğa ile uyu \\
\end{tabular} & & $\sqrt{ }$ & $\sqrt{ }$ & $\sqrt{ }$ & $\sqrt{ }$ & $\sqrt{ }$ & $\sqrt{ }$ & $\sqrt{ }$ & $\sqrt{ }$ & $\sqrt{ }$ & $\sqrt{ }$ & $\sqrt{ }$ & $\sqrt{ }$ & $\sqrt{ }$ & $\sqrt{ }$ & $\sqrt{ }$ \\
\hline 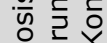 & İklim şartları & a uygunluğu & $\sqrt{ }$ & $\sqrt{ }$ & $\sqrt{ }$ & $\sqrt{ }$ & $\sqrt{ }$ & $\sqrt{ }$ & $\sqrt{ }$ & $\sqrt{ }$ & $\sqrt{ }$ & $\sqrt{ }$ & $\sqrt{ }$ & $\sqrt{ }$ & $\sqrt{ }$ & $\sqrt{ }$ & $\sqrt{ }$ \\
\hline ע & \begin{tabular}{|l} 
Tasarımda dc \\
\end{tabular} & jal konturları koru. & $\sqrt{ }$ & $\sqrt{ }$ & $\sqrt{ }$ & $\sqrt{ }$ & $\sqrt{ }$ & $\sqrt{ }$ & $\sqrt{ }$ & $\sqrt{ }$ & $\sqrt{ }$ & $\sqrt{ }$ & $\sqrt{ }$ & $\sqrt{ }$ & $\sqrt{ }$ & $\sqrt{ }$ & $\sqrt{ }$ \\
\hline & İşitsel konfor & n sağlanması & & & & & & & & & & & & & & & \\
\hline
\end{tabular}


Malzeme kriterine göre serenderler irdelendiğinde tamamında ahşap, taş gibi doğal, yerel, daha az bakım gerektiren ve geri dönüşüme uygun malzeme kullanımı tespit edilmiştir. Ayrıca zaman içerisinde serenderlerin çatısında ve tekerlerdeki yıpranma, eskime sonucu sac, çinko gibi yapay malzeme kullanımı da gözlenmiştir. Kolonlarla yerden yükseltilmiş serendere ulaşım genellikle ahşap, seyyar bir merdivenle sağlanırken Tonya ilçesindeki örneklerde çevresel koşullar nedeniyle deforme olan ahşap merdivenlerinin yerine betonarme merdiven yapıldığı tespit edilmiştir.

Ekosistemi koruma ve konfor kriterleri açısından serenderlere bakıldığında direklerle yerden yükseltilmesi, az katlı olması, yapımında doğal-yerel malzeme kullanılması, serenderlerin topoğrafyaya uygun şekilde konumlanması, iklim şartlarına uygunluğu tasarımında doğal konturların korunmasını sağlamıştır.

Serenderlerin sökülüp takılabilmesi, başka bir yere taşınabilmesi, yapımında kullanılan ana malzeme olan ahşabın hafif ve esnek yapısının iş gücünün hafif olmasına katkı sağladığı düşünülmektedir. Yukarıda belirtilen özelliklerle birlikte serenderlerin yapımında doğal, yerel, daha az bakım gerektiren, geri dönüşüme olanak veren malzeme kullanılması, topoğrafyaya uygun şekilde inşa edilmesi serenderlerin doğa dostu, ekolojik ve sürdürülebilir yapılar olduğunun en güçlü göstergeleridir. Bu bağlamda Şekil 17'de genel bir serender plan ve cephesi üzerinden serenderlerin ekolojik ve sürdürülebilir nitelikleri şematik olarak ifade edilmiştir.
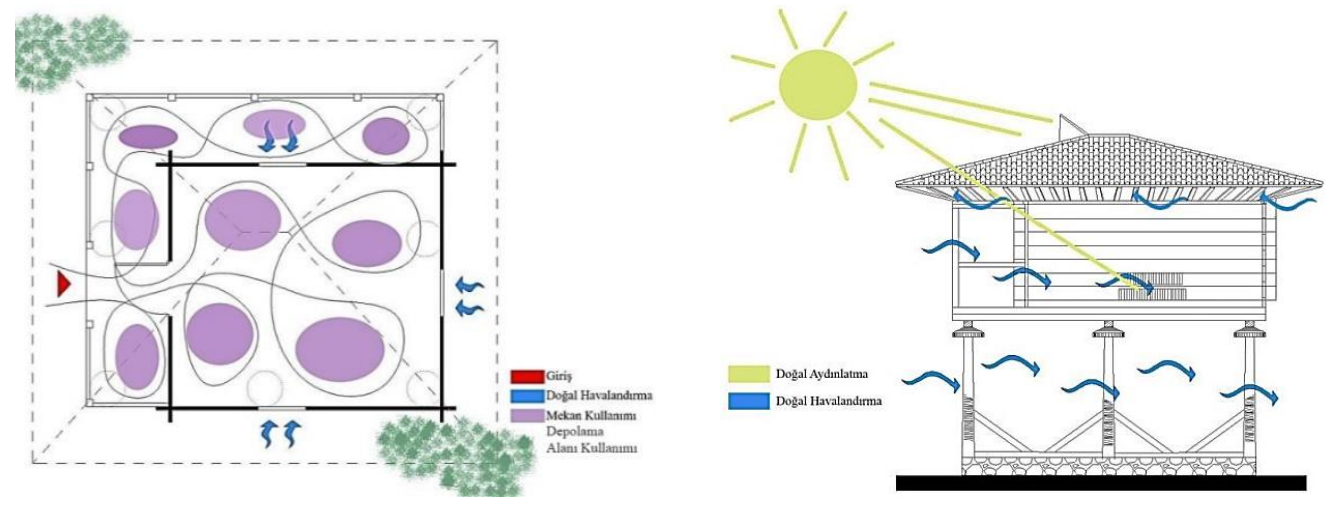

Şekil 17. Serender planı ve cephesi üzerinden ekoloji ve sürdürülebilirlik analizi

Şekil 17'ye bakıldığında yapay ve doğal aydıntlamanın kullanılmadığı serenderlerde çatı fenerleri, havalandırma boşlukları sayesinde iç mekanın doğal havalandırma ve aydınlatmaya sahip olduğu görülmektedir. Ayrıca ahşap bölücü elemanlar ile serenderlerin iç mekanı farklı kullanım ve depolama alanlarına dönüşebilmektedir.

\section{SONUÇ VE ÖNERÍLER}

Unutulmaya yüz tutmuş kültür mirasımızın önemli değerlerinden olan serenderlerin ekolojik ve sürdürülebilirlik özelliklerini ele alarak yeniden canlandırılmasında, gelecek nesillere aktarımının sağlanmasında farkındalık yaratmak amacıyla Doğu Karadeniz Bölgesi'nin Trabzon ilinin Araklı, Sürmene ve Tonya ilçelerindeki serenderler çalışma kapsamında incelenmiştir. Elde edilen bulgular sonucunda serenderlerin ekolojik ve sürdürebilirlik kriterlerine uyumlu oldukları saptanmıştır.

Ahşap yığma ve karkas sistemlerinin birlikte kullanıldığı serenderler geleneksel yapım tekniklerinin sergilendiği önemli mimari ürünlerdir. Ancak ahşabın yağmur, kar, güneş vb. doğal faktörlerden olumsuz etkilenmesi sonucu serenderlerin taşıyıcılığının artırılması için ahşap dikmelerin betonarme kolonlarla değiştirilmesi orijinal yapısını bozarak yapay bir görünüm oluşturmaktadır. Serenderlerin daha çok depo amacı ile kullanılması nedeniyle ıSı, ses, yangın yalıtımının yapılmadığı ve güneş kontrol elemanlarının kullanılmadığı düşünülmektedir. Yapımında kullanılan ana malzemenin ahşap olması, yapı elemanlarının sökülüp takılabilmesi ve başka yere kolaylıkla taşınabilmesi, yapımında yerel malzeme kullanılıp, işçiliğinde yöredeki ustaların görev alması serenderlerin fazla enerji harcamadan üretilmesini sağlamaktadır. 
Doğal havalandırma-aydınlatma, doğal, yerel, daha az bakım gerektiren, geri dönüşüme uygun malzeme kullanımı, içinde yer aldığı çevrenin doğal konturlarını bozmayan, topoğrafyaya uyumlu konumu gibi ekolojik ve sürdürülebilir tasarımın önemli kriterlerine sahip serenderler doğa dostu olmakla birlikte kültürel mirasın da değerli parçalarındandır. Ne yazık ki bu önemli geleneksel mimari örneklere gereken önem verilmemekte, kullanıcının bilinçsizliği, imkanlarının yetersizliği nedeniyle birçoğu yıkılmış, bakımsız ve unutulmaya yüz tutmuş durumdadır.

Elde edilen veriler ışığında serenderlerin korunması, gelecek nesillere aktarılması, serender kültürünün yaşatılması için aşağıda birtakım öneriler sunulmuştur;

- Köyden kente göçlerin artması ve yeni yapım tekniklerinin kullanıldığı yapıların inşa edilmesi sonucu kırsaldaki serenderler bakımsız kalmış veya yerine yeni bir ev, depo vb. yapmak için yıkılmıştır. Bu nedenle sayıları gittikçe azalan serenderlerin korunması için devletin ilgili kurumları tarafından kırsaldaki serenderler tespit edilerek kimlik kartları oluşturulmalı ve tescil edilmelidir. Yerel halk serenderlere sahip çıkılması konusunda bilinçlendirmeli, fiziksel koşulları kötü olan serenderlerin yenilenmesi için maddi destek, proje ve işçilik imkanı sağlanmasına dönük çalışmalar yapılmalıdır.

- Geleneksel yapım sistemlerinin günümüzde fazla kullanılmaması nedeniyle bu teknikleri uygulayan ustaların sayısı gittikçe azalmakta, yeni nesiller ise bu konuda hiçbir bilgiye sahip olmamaktadır. Bu bağlamda kültürümüzün bir parçası olan geleneksel yapım sistemlerinin yerel ustalar tarafından kuşaktan kuşağa aktarılmasını sağlayan kurslar açılarak hem bu tekniklerin sürekliliği hem de serender ve diğer geleneksel yapıların bilinçli bir şekilde bakım ve yenilenme çalışmalarının yapılmasının önündeki işgücü problemi çözülebilir.

- Mevcut serenderlerin sadece depo olarak kullanılması yerine günümüzün yaşantısına uygun olarak oturma, dinlenme, misafir evi gibi yeni işlevler kazandırılabilir, bu sayede serenderlerin aktif kullanımı sağlanmış olur.

- Serenderlerin doğal havalandırma ve kolonlarla yerden yükseltilmesi özelliğinden yararlanarak sıcak bölgelerde veya yaylalarda özel mimari yapısıyla yerli ve yabancı turistin ilgisini çekecek tatil köyleri tasarlanabilir. Ayrıca parklarda yeme-içme hizmeti veren kafe olarak kullanılabilir.

- Serenderlerin biçimsel ve işlevsel özelliklerinden yararlanarak yeni yapılacak serenderlerde geleneksel malzeme olan ahşap ve taş kullanımına çelik, cam vb. modern malzemeler entegre edilebilir.

- Yeni yapılacak serenderlerde modern ile geleneksel yapım teknikleri birlikte uygulanabilir.

Günümüzün yapılandırımış çevreleri, üretmeye ve korumaya çalıştığımız kültürel, doğal ve yaşamsal ihtiyaçlarımıza cevap verememektedir. Teknolojik ve ekonomik ilerlemelere hızlı adapte olan "gelişmiş" insanlar, doğaya meydan okuyan binalarda yaşamlarını sürdürmeye başlayarak ekolojik zihniyet yerini endüstriyel zihniyete bırakmıştır. Bu durumun sonucu olarak da yapıda kullanılan malzemeler ve teknolojik kapalı ortamlardan kaynaklanan hava kirleticilerinin yoğunlukları, zehirler, elektromanyetik radyasyon giderek artarak insan metabolizmasını ve doğayı olumsuz yönde etkilemektedir (Akman, 2019). Bu bağlamda doğaya ve toplum intiyaçlarına göre şekillenen kırsal mimari ürünlerinin temelinde yatan ilke ve detayların günümüz mimarisinde de yorumlanıp kullanılması hem kültürel sürekliliği sağlanması hem de sağlıkı bir çevre oluşturulmasına katkı sağlayacaktır.

\section{KAYNAKLAR}

Akansel, Ş., Kaprol, T., Varlı, E., Gencer, İ. (2009). Sürdürülebilir Kırsal Konut Planlamasında Kamu/Üniversite İşbirliği: Edirne Örneği. Uluslararası Ekolojik Mimarlık ve Planlama Sempozyumu, Mimarlar Odası Antalya Şubesi Adına Yayına Hazırlayanlar: Pınar Engincan Bol, Hüseyin Yaşar, Mürüvvet Uçak, Mimarlar Odası Antalya Şubesi Yayınları, 12/ 12, 2225 Ekim, Antalya, Turkey, ss. 227-230. 
Akman, A. (2019). Şehirde Mevcut Olmak ya da Gelişmiş Kırsalda Yaşamak, In: A. Ciravoğlu (Eds.), Ters Köşe Ekoloji, İstanbul: Puna Yayın.

Aksoylu, K. (2012). Karadeniz Deyince. In: T. Bora (Eds.), Derleyen, Uğur Biryol, Karardı Karadeniz, İletişim Yayınları 1771, 1-2 Baskı, İstanbul, s. 52- 54.

Aktuna, M. (2007). Geleneksel Mimaride Binaların Sürdürülebilir Tasarım Kriterleri Bağlamında Değerlendirilmesi Antalya Kaleiçi Evleri Örneği, Yüksek Lisans Tezi, Yıldız Teknik Üniversitesi, Fen Bilimleri Enstitüsü, İstanbul.

Aran, K. (2000). Barınaktan Öte Anadolu Kır Yapıları, İstanbul: Ofset Yapımevi, ss. 14-15.

Batur, A., Gür, Ş. (2005). Doğu Karadeniz'de Kırsal Mimari. Birinci Baskı, İstanbul: Milli Reasürans T.A.Ş Yayını.

Ceylan, S. (2010). Kırsal Mimarinin Örneklerinden " Serenler"in Coğrafi Açıdan İrdelenmesi, Doğu Coğrafya Dergisi, 17(27), ss. 151- 168.

Demir, N. (2004). Trabzon ve Yöresinde Serenderler (Serender In Trabzon And Its Territory) Erdem Atatürk Kültür Merkezi Dergisi, Cilt 14, Sayı 41, ss. 99-118.

Eruzun, C. (1977). Doğu Karadeniz'de Serenderler, I. Uluslararası Türk Folklor Kongresi Bildirileri, V. Cilt Etnografya, Kültür Bakanlığı Milli Folklor Araştırma Dairesi Yayınları: 22, Akın Matbaası, Ankara, ss.125-139.

Ford, A. (2007). Designing The Sustainable School. Australia: The Images Publishing Group.

İnanç, T. (2010). Geleneksel Kırsal Mimari Kimliğin Ekoloji Ve Sürdürülebilirlik Bağlamında Değerlendirilmesi Rize Çağlayan Köyü Evleri Örneği, Yüksek Lisans Tezi, Mimar Sinan Güzel Sanatlar Üniversitesi, Fen Bilimleri Enstitüsü, İstanbul.

İskender, M. (2010). Dünyada Serander Mimarisi. Karadeniz Hayat, 6, ss. 70-71.

Karpuz, H. (1999). Serander ve Loft Türk ve Norveç Halk Mimarisinde Eşdeğerli İki Yapı ('Serander' and 'Loft': Two Identıcal Buıldıng Types In The Turkısh And Norvegian Vernacular Architecture). ODTÜ MFD, 19, 1-2, ss. 71-82.

Lakot Alemdağ, E., Al Şensoy, S. (2018). Evaluatıon Of Sustaınabılıty Concept At K12 School, Arch Desıgn '18 / V. Internatıonal Architectural Desıgn Conference, Conference Proceedıngs, İstanbul, ss. 535-547.

Özek, V., Kısa Ovalı, P. (2007). Ekolojik Mimarlıkta Binaların Enerji Gereksinimini Azaltmaya Yönelik Ölçütler ve Ülkemiz İçin Önemi, Ekolojik Mimarlık ve Planlama Ulusal Sempozyumu, 27-28 Nisan, Antalya, ss. 166-172.

Özgel Felek, S. (2020). Doğu Karadeniz Yerel Mimariye Ait Serender ve Dünya'dan Benzer Yapılar (Types Of Serender In The Eastern Black Sea Local Architecture And Similar Architectural Structures In The World), Karadeniz İncelemeleri Dergisi, (28), ss. 525-546.

Özgüner, O. (1970). Köyde Mimari Doğu Karadeniz. Ankara: ODTÜ Mimarlık Fakültesi Yayınları.

Sağsöz, A., Elmalı Şen, D., Candaş Kahya, N., Midilli Sarı, R., Özgen, S. (2008). Doğu Karadeniz Bölgesi Doğal Sitleri ve Vernaküler Mimarisi, TMMOB Mimarlar Odası, Sürekli Mesleki Gelişim Merkezi (SMGM) Seminerleri Ders Notu.

Sev, A. (2009). Sürdürülebilir Mimarlık, İstanbul: YEM Yayınları.

Sümerkan, M.R. (2008). Doğu Karadeniz'de Geleneksel Yapı Kültürümüzün Açık Hava Müzesi Fındıklı Köy Evleri, In: Y. Yıldırımkaya, Z. Sarıhan (Eds.), Rize'de Fındıklı ve Güneysu Kırsal Mimarisi, İstanbul: Umur Basım.

Sümerkan, M.R. (2019). Rize Geleneksel Köy Evlerinde Mekan Kullanımı ve Plan Tipleri, Ed. Haşim Karpuz, Geleneksel Rize Mimarisi Üzerine Araştırmalar, Revak Yayınları, İstanbul, 79-128.

Topaloğlu, İ. (1998). Bölge Tarihinde Rize, Topaloğulları Kültür- Dayanışma ve Çevre Koruma Derneği, Birinci Cilt, Trabzon, ss.123- 124.

Tuna, C. (2008).Orta Karadeniz Bölgesi Sahil Kesiminde Geleneksel Mimari, İstanbul: Arkeoloji ve Sanat Yayınları.

URL-1, (2019). http://www.kuriositas.com/2011/07/horreo-singular-symbols-of-spain.html (accessed in: 05. 03 .2019), (In English). 
URL-2, (2019).https://kiwidutch.wordpress.com/2010/12/08/new-199/ (accessed in: 05.03.2019), (In English).

URL-3， (2019).http://serenderevler.com/dunyada-ve-turkiyede-serender-kulturu-2/ (accessed in: 19.06.2019), (In Turkish).

Yeang, K. (2012). Ekotasarım Ekolojik Tasarım Rehberi, (Çeviren, Semih Eryıldız, Demet Eryıldız,),(Ed., Yılmaz, B.,). İstanbul: YEM Yayınları.

Yılmaz, A. (2007). Karadeniz'in İncisi Serander. İstanbul: Trabzon Dernekler Birliği Kültür Yayınları, Ema Matbaacılık. ,

Yudelson, J. (2007). Green Building A to Z, Understanding the Language of Green Building. Canada: New Society Publishers.

\section{EXTENDED ABSTRACT}

Rural architecture, representing human-environmental interactions, is not only compatible with natural formation where available but also reveals local architectural identity. Rural architecture, an expression of cultural reflection of human reactions to hard living conditions, occupies an important position in life of community, who is attached to their customs and traditions.

Throughout the human history, individuals have needed certain places in order to maintain their lives. In almost every countryside area, it is likely that there is a secondary privatized structure next to each residential building. "Serender", one of the secondary structures, erected next to residential buildings are one of the plainest patterns of rational and practical solutions found by locals for natural conditions due to local building materials which they are made of as well as authentic structural and architectural richness (İskender, 2010).

People living in the countryside have migrated to towns for a variety of reasons such as unemployment, limited resources, transportation problems, topographic structure, need for shelter. They who are distanced from rural formation have got away from their own cultures and traditions and eventually adopted urban life, which has caused these traditional structure patterns to lose their function and importance. Environment friendly "Serender" complying with peerless beauty of nature are also among traditional structures which lose function and significance. In this regard, the aim of the research is to enlighten next generations about "serender" which have fallen into oblivion and lost its function, maintain the significance of traditional structures, and ensure their existential continuity.

Even though their characteristic formation, construction techniques and structures are different, it can be said that traditional architecture which is based on local and natural materials underlies the notion of ecologic and sustainable architecture creating today naturefriendly architectural practices and having rational solutions that correspond to environmental conditions where available.

In this study, "serender ", a traditional building type, which are found in countryside areas of the towns of Sürmene, Tonya and Araklı, the city of Trabzon, located in Eastern Black Sea region, Turkiye are examined. In total 15 serenders, 5 in each one of the mentioned-above towns, are selected in order to examine on-site in terms of ecology and sustainability. The data related to the serender including their architectural introduction, images, location, neighborhood group, usage status, plan type, area (semi-open and closed) and current function are presented in table."

At the very beginning of the study, an extensive literature review was made with reference to traditional architecture, serender, ecology and sustainability. In the light of information obtained from the literature, the criteria of ecology and sustainability were determined and then a check-list was made for the serenders. The check-list consists of the criteria such as number of columns, location of bower, formation of building, orientation, wheel material (wooden, stone), flexible space use, use of traditional structural systems, temperature, sound, fire insulation, use of solar control elements, use of renewable energy sources, lightness of labor, natural draught, artificial ventilation, natural lighting, artificial lighting, use of natural material, use of local material, use of low-maintenance material, use of recycled material, 
being positioned in accordance with topography, compatibility with nature, compatibility with climate conditions, protection of natural contours in design, optimization of audial comfort. In the field operations, the survey books of the serenders were prepared, the photos of the houses were taken, and the locals were interviewed with. Moreover, the serender were analyzed as part of the check-list including the criteria of ecology and sustainability.

The findings obtained from the research conducted for the purpose of creating awareness of revitalizing and handing down the next generations denote that the serender, a part of cultural heritage, which have passed into oblivion correspond to the criteria of ecology and sustainability.

Consequently, it is possible to say that discussing and applying principles and details which lie behind rural architecture works shaped according to nature and community needs will make a contribution today to providing a healthy environment. 